\title{
110 Years of Orthopteran Cytogenetics, the Chromosomal Evolutionary Viewpoint, and Michael White's Signal Contributions to the Field
}

\author{
Author(s): Claudio J. Bidau and Dardo A. Martí \\ Source: Journal of Orthoptera Research, 19(2):165-182. 2010. \\ Published By: Orthopterists' Society \\ URL: http://www.bioone.org/doi/full/10.1665/034.019.0202
}

BioOne (www.bioone.org) is an electronic aggregator of bioscience research content, and the online home to over 160 journals and books published by not-for-profit societies, associations, museums, institutions, and presses.

Your use of this PDF, the BioOne Web site, and all posted and associated content indicates your acceptance of BioOne's Terms of Use, available at www.bioone.org/page/terms_of_use.

Usage of BioOne content is strictly limited to personal, educational, and non-commercial use. Commercial inquiries or rights and permissions requests should be directed to the individual publisher as copyright holder. 


\title{
110 years of orthopteran cytogenetics, the chromosomal evolutionary viewpoint, and Michael White's signal contributions to the field*
}

Submitted November 11, 2010, accepted December 5, 2010

\author{
Claudio J. Bidau and Dardo A. Martí
}

(CJB) Paraná y Los Claveles, 3304 Garupá, Misiones, Argentina. E-mail: bidau47@yahoo.com

(DAM) Laboratorio de Genética Evolutiva, Facultad de Ciencias Exactas, Químicas y Naturales, Universidad Nacional de Misiones, 3300 Posadas, Misiones, Argentina. CONICET. E-mail: darmarti@yahoo.com.ar

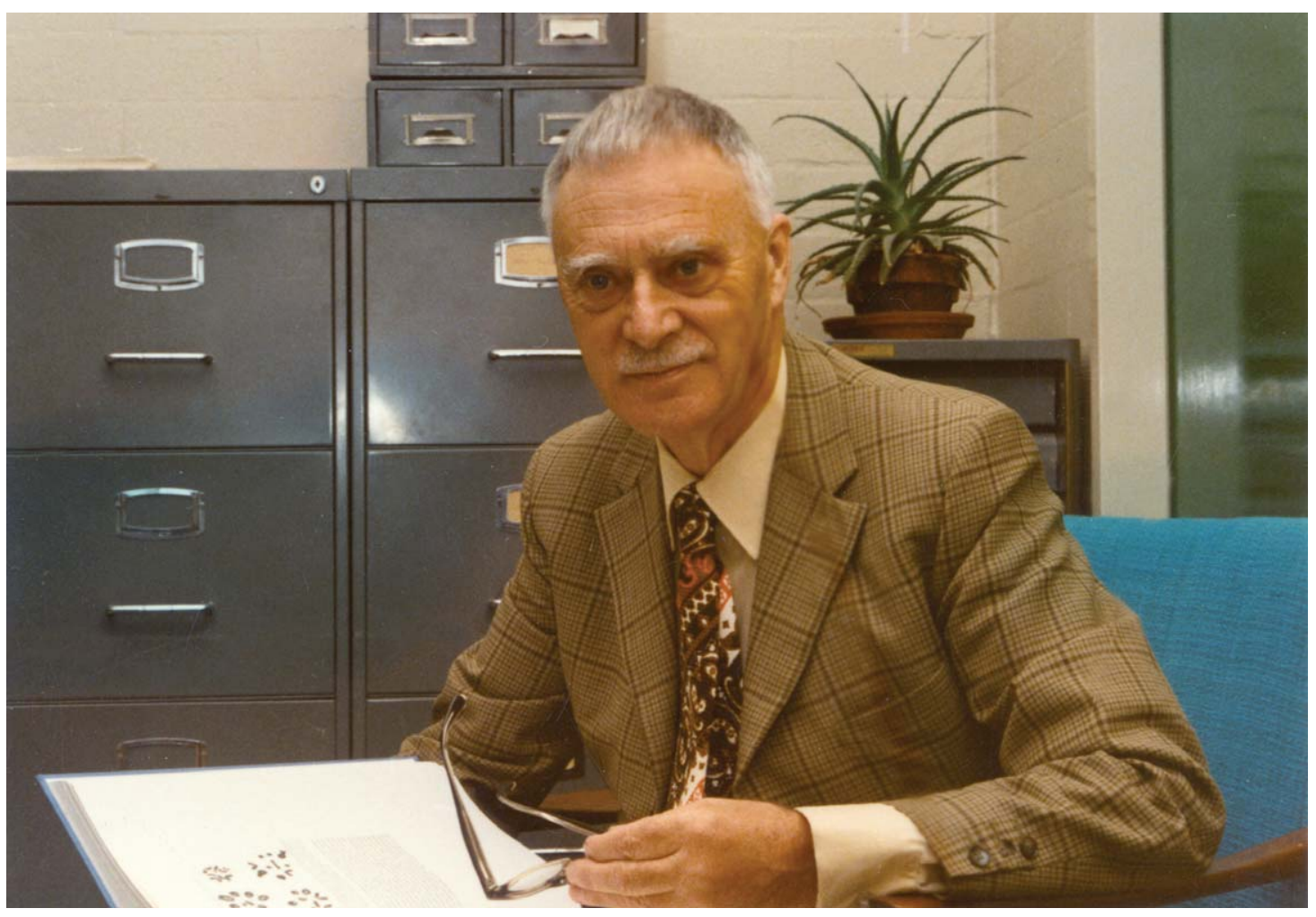

\begin{abstract}
The history of the study of orthopteran chromosomes is coincident with the formulation of the chromosome theory of heredity and the rediscovery of Mendel's laws, thus with the birth of cytogenetics. We review the early contributions of grasshopper chromosomes to the chromosome theory, the understanding of sex chromosomes, the phenomena of mitosis, meiosis, linkage, crossing over and recombination, the problems of chiasma localization and terminalization, reproduction and parthenogenesis, the nature and behavior of B chromosomes and supernumerary segments, and the role of chromosomal rearrangements in microevolution and speciation. We also discuss the influence of early works on later research, and emphasize the fundamental contributions of Michael J. D. White to modern cytogenetics and evolutionary biology in general.
\end{abstract}

\section{Key words}

chromosomal speciation, chromosome theory, history of cytogenetics, meiosis, Michael White, population cytogenetics

*Dedicated with admiration to Estrella Eleanor Carothers, Nettie Maria Stevens, Mary Harman, Marcella O'Grady, and Sally Hughes, brilliant scientists that paved the road to our understanding of chromosomes. "...one of the finest objects thus far discovered for the investigation of the minutest details of cell structure."

Quote from Edmund Beecher Wilson when shown Brachystola magna chromosomes for the first time.

The Orthoptera in early cytogenetics: Mendel's principles and big chromosomes.-The history of cytogenetics will be forever intimately associated with the Orthoptera. Cytogenetics was born at the beginning of the twentieth century, with the combination of the already well-developed science of cytology and the 'rediscovery' of Mendel's principles in 1900 separately by three scientists: DeVries, Correns and Tschermak (Crow \& Crow 2002, Falk 2005, Schwartz 2008).

Clarence Erwin McClung, a pioneer in grasshopper cytology, once wrote: 'A subject of perennial interest is offered by the maturing germ cells, and that appreciation is not lacking is well evidenced by the large annual output of papers devoted to different phases of the question. The task of keeping abreast of this literature has become a considerable one, especially since it is now necessary to take into account the investigations upon hybrid matings and upon unusual or modified methods of fertilization. Despite regret at the increased labor thus brought about, one 

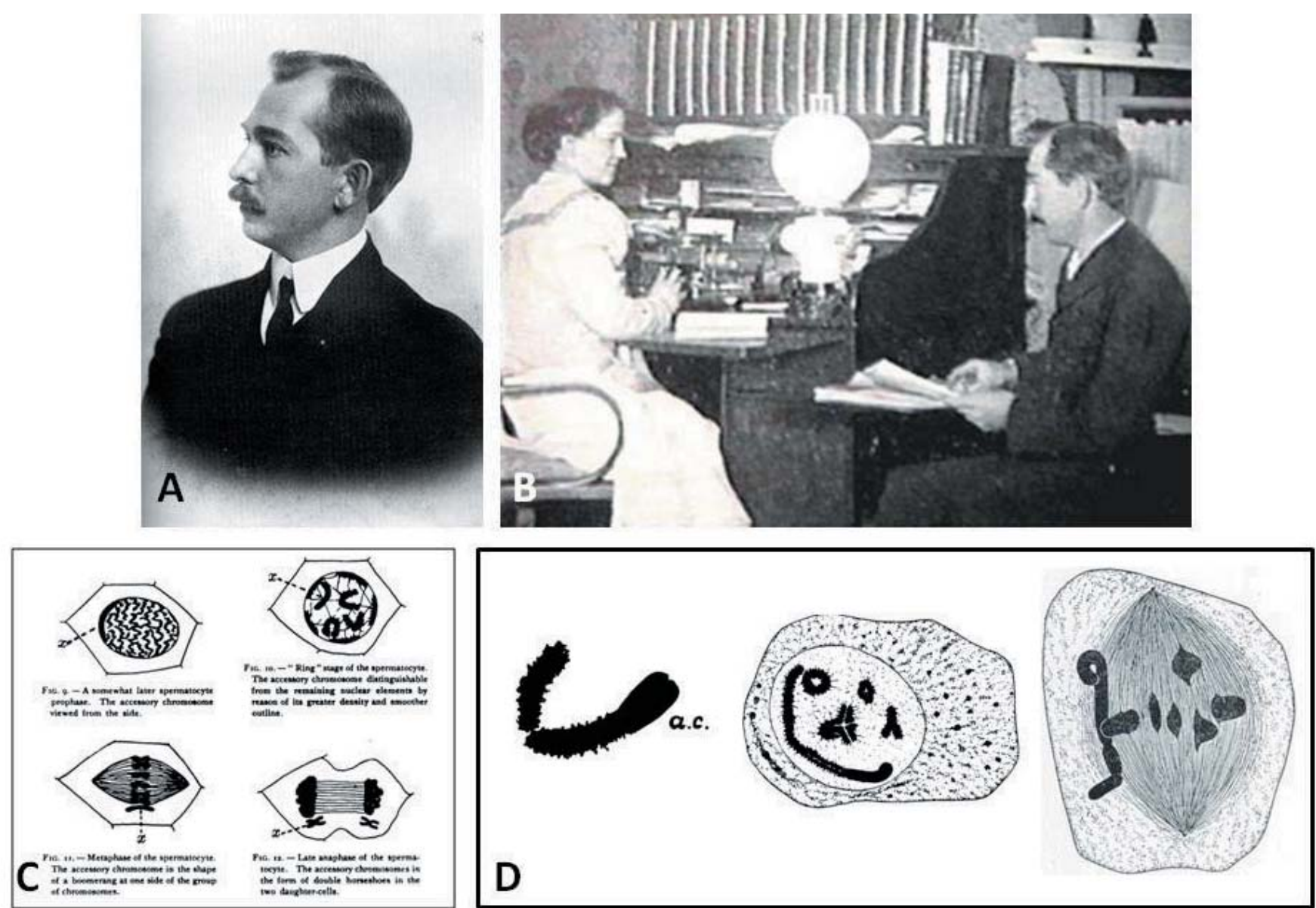

Fig. 1. Clarence McClung and the beginnings of orthopteran cytogenetics. A. McClung; B. McClung and his wife; C. Meiotic cells of Xiphidium fasciatum (Conocephalus fasciatus) showing the 'accessory (X) chromosome' from the 1899 paper (from McClung 1899, Zoological Bulletin 2: 187-197.); D. The first published figures of neo-XY chromosomes of Orthoptera; from left to right, the neo-XY bivalent of Hesperotettix, partial diplotene cell of Mermiria showing the neo-XY bivalent, idem at first metaphase (from McClung 1917, J. Morphol. 29: 519-605.),

cannot but rejoice at the enlarged conceptions of chromosome functions which have followed from this union of two apparently different lines of investigation.' (McClung 1905).

Chromosomes of grasshoppers and crickets were instrumental in the development of the Chromosome Theory of Heredity (or Sutton-Boveri theory) (Ault 1996). In recent years some doubts were cast on the real provenance of the theory: the respective contributions of the two classic authors (Martins 1999), the neglected participation of Boveri's wife Marcella O'Grady, she being a former student of E. B. Wilson's (Satzinger 2005), and consideration by some modern authors of Thomas Hunt Morgan as the real father of the chromosome hypothesis (although initially, he was a fierce opponent of the theory) (Castillo et al. 2010, Brush 2002). This is notwithstanding the outstanding work of Walter Stanborough Sutton, a disciple of McClung's and of Edmund Beecher Wilson (Figs 1, 3 ), on the meiotic chromosomes of the western lubber grasshopper Brachystola magna (Romaleidae) (Sutton 1900, 1902, 1903). Helaid the foundations of a completely new field, cytogenetics, and of the final acceptance that the behavior of genes in eukaryote heredity rests on the mechanics of the meiotic process (Crow \& Crow 2002).

Sutton first collected B. magna in the summer of 1899 while working at his parents' ranch in Kansas where literally thousands of lubber grasshoppers were hopping around in the wheat fields. Cells and chromosomes of this species were so large and easy to observe microscopically that the amazed McClung urged Sutton to immediately start research on its chromosomes (Schwartz 2008).
It has to be admitted that Sutton's work rested mainly upon careful microscopic observation, interpretation and speculative thinking, and not upon experimental data (Martins 1999). It is also true that some of his interpretations were erroneous and that these mistakes produced several years of confusion regarding the actual mechanism of chromosomal synapsis and segregation [Sutton erroneously considered that the second meiotic division was reductional and the first, equational, probably influenced by the ideas of McClung, Wilson and Montgomery (Hegreness \& Meselson 2007)]. Nevertheless, his conclusions on the existence of two sets of homologous chromosomes (maternal and paternal) that synapse at the beginning of meiosis, on the integrity of chromosomes through cell divisions, and his hypothesis (based on an extrapolation of genetic data and not on his cytological observations) that chromosome orientation was random with respect to the spindle poles (contra Cannon 1902), were essentially correct - based on observations of an extremely favorable material and on his technical dexterity (Sutton 1902, 1903; Crow \& Crow 2002).

Sutton's work also constituted a physical basis for Mendelian principles, and indicated, as earlier research by Theodor Boveri on sea urchin eggs had suggested (Boveri 1902), that each chromosome was unique and contained a set of distinct hereditary factors. This was later proven without any doubt by Thomas Hunt Morgan's Drosophila group at Columbia, despite Morgan's initial opposition to the chromosome theory (Morgan et al. 1915, Benson 2001).

A further and relevant development of Sutton's discovery was 

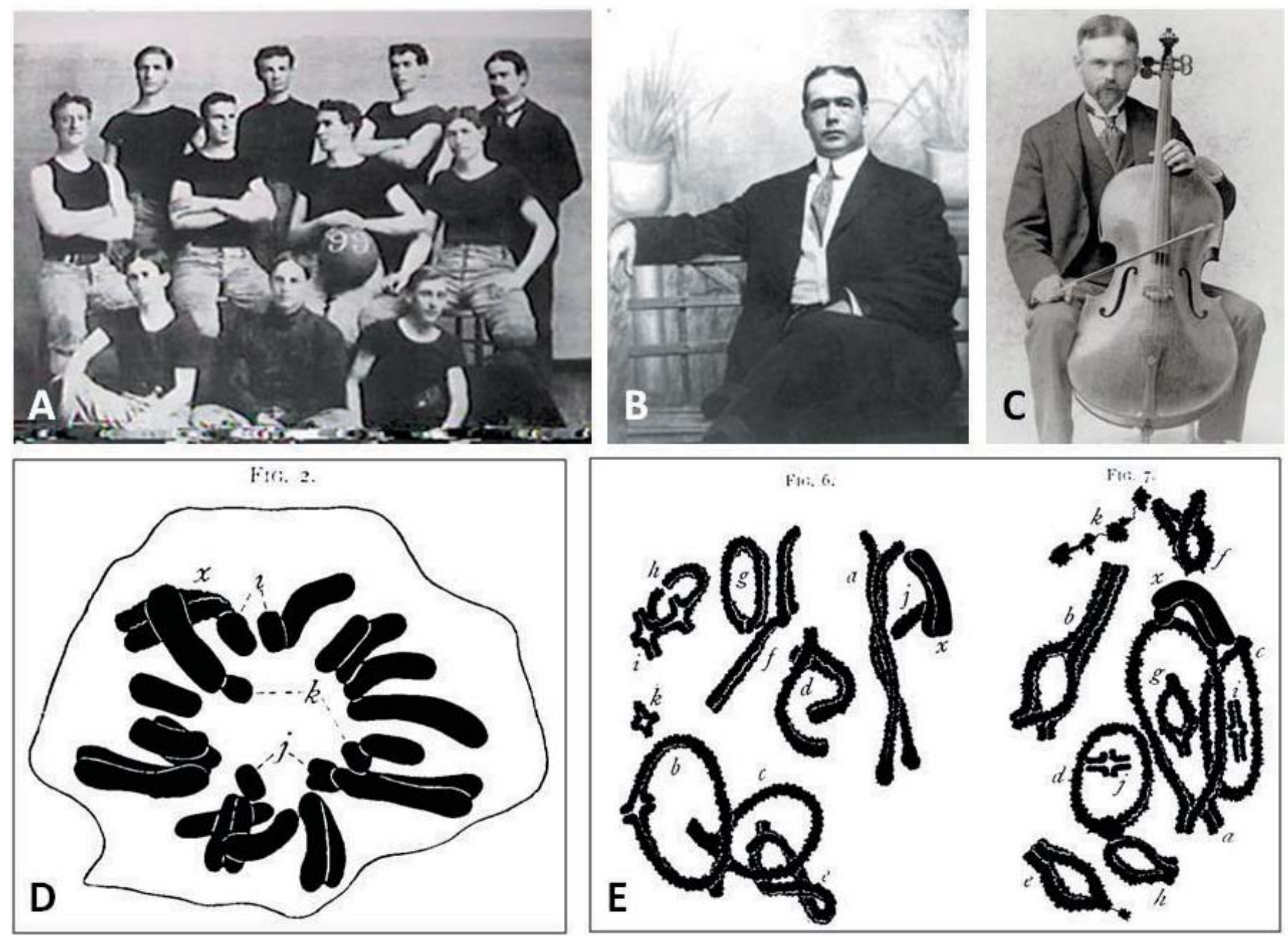

Fig. 2. Walter Stanborough Sutton and the Chromosome Theory of Inheritance. A. The first basketball team of the University of Kansas (1899); Sutton is third from the left (back row); his brother William, team captain, is in the middle row (third from the left); B. Sutton ca 1905 when he returned to Columbia University to complete his medical studies; C. Edmund Beecher Wilson in whose lab Sutton completed his last and fundamental paper on Brachystola magna; Wilson is shown with one of his passions, the cello; D. Spermatogonial metaphase of B. magna; E. Two diplotene cells of B. magna; note that chiasmata and the duplicated nature of all chromosomes, are clearly depicted. Figures D. and E. from Sutton 1902; Biological Bulletin 4: 231-251.

made by Estrella Eleanor Carothers (1883-1957) using grasshopper meiotic material (Fig. 2). Carothers followed Sutton as McClung's student at the University of Kansas. At McClung's laboratory, she had the opportunity to re-analyze some of Sutton's B. magna slides, as well as new ones she made herself (Hegreness \& Meselson 2007). Although Sutton correctly interpreted that chromosomes come in homologous pairs, one chromosome maternal, the other chromosome paternal, he could not possibly identify each member of a pair, due to inherent technical limitations at that time. However, Carothers took advantage of a known fact, that of the univalence of the X [then called "accessory" chromosome by McClung (McClung 1901, 1902; Castillo et al. 2010)] in males, and of her own observation (in Sutton's slides) that some individuals carried a heteromorphic autosomal pair: thus, both homologues could be microscopically identified according to size (Carothers 1913). Through the analysis of a large number of meiotic divisions, she was able to document their independent orientation behavior with respect to the spindle poles and their random segregation (as suggested by Sutton), thus producing the first physical evidence of Mendel's laws: segregation and independent assortment.

She was obviously not able to extend her conclusions to the rest of the chromosome pairs where again, maternal and paternal homologues were unidentifiable. This perpetuated the uncertainty as to the moment of the reductional division (Hegreness \& Meselson 2007). Although Edmund Beecher Wilson, one of the leading cytologists of that time suspected that not only heteromorphic bivalents (or univalents), but all bivalents experienced reduction at first division (Wilson 1925), the confusion persisted in the following papers by Carothers $(1917,1921,1926,1931)$ in which she studied segregation of heteromorphic bivalents of several other orthopteran genera such as Circotettix, Trimerotropis, Mecosthetus and Amphitornis.

Although her results confirmed the independent assortment of maternal and paternal chromosomes, she remained undecided as to the generality of reduction in the first meiotic division, considering that it could be just a property of heteromorphic bivalents and the sex chromosome (Hegreness \& Meselson 2007). With hindsight, we can now say that the solution was implicit in the same meiotic cells she was studying, because such heteromorphic autosomes, which are very common in grasshoppers (Nur 1961, John 1973, Bidau \& Hasson 1984), usually result from heterochromatic supernumerary segments (see below), and the position of chiasmata (distal or proximal to the segment) determines the mode of segregation 
of the heteromorphic bivalent during first meiosis (reductional or equational, respectively).

Notably, one year after the publication of Carother's 1931 paper, Darlington (1932) correctly interpreted her images of heteromorphic bivalents and established that first division is reductional with respect to the centromere and the region between it and the first chiasma, while the portion distal to the chiasma undergoes equational segregation (Darlington 1958, Hegreness \& Meselson 2007). Errors of interpretation notwithstanding, the contributions of Estrella Eleanor Carothers to the chromosome theory and to orthopteran cytology were of fundamental relevance to the advancement of genetics. Carothers was also fortunate that the riddle of sex chromosomes was being disentangled at the same time.

The Orthoptera in early cytogenetics: the elusive 'accessory' chromosome.-The issue of chromosomal sex determination has a long history and orthopterans were involved in it from the very beginning. The historical aspects of the discovery of sex chromosomes, their contribution to the chromosome theory, and the fundamental role of grasshopper cytology in elucidating their true nature, are discussed by Castillo et al. (2010) in this same issue, thus we will treat the problem succinctly, emphasizing Michael White's contribution to their knowledge.

Although orthopteran cytology started in the late nineteenth century (Castillo et al. 2010), the first relevant contriubutions to the chromosome theory were published by McClung $(1899,1900)$ with his identification of the 'accessory chromosome' as a true chromatin body and not a nucleolus. Further work by McClung (1901, 1902) (Fig. 3) correctly identified the accessory chromosome (soon to be called 'X-chromosome') as a sex determinant and prompted a number of studies by himself and other researchers that corroborated his insight (McClung 1905, 1914; Davies 1908; Pinney 1908; Robertson 1908; Büchner 1909; Payne 1909, 1912; Meek 1911; Wenrich 1916).

Essential to the understanding of the nature and role of sex chromosomes was the brilliant work of Nettie Stevens who studied spermatogenesis in a large number of insects of different orders, including Orthoptera (Stevens 1905, Castillo et al. 2010 and references therein). Stevens also (1908a) correctly identified the X and Y chromosomes of Drosophila, which was fundamental to the precise localization of the first mutation (white) by Morgan and his group (Morgan et al. 1915).

The study of orthopteran sex chromosomes was also fundamental to an understanding that chromosomes, though stable in principle, were entities that could evolve and interact between each other through chromosomal rearrangement, as early demonstrated by the existence of neo-sex mechanisms that derived from translocation between the X chromosome and an autosome (McClung 1917, Castillo et al. 2010).

In the same sense, Michael White's studies in Orthoptera and Mantodea cytogenetics were of relevance for the understanding of the evolution of sex chromosomes (White 1945, 1977). White's (1940a) first paper dealing with orthopteran sex chromosomes was a lengthy discussion about their heteropycnosis in different stages of mitosis and meiosis.

It has been known since the beginnings of cytogenetics that the X chromosome of Orthoptera (and many other organisms) is positively heteropycnotic during most of prophase I, becoming negatively heteropycnotic during metaphase $\mathrm{I}$. The $\mathrm{X}$ is also negatively heteropycnotic during spermatogonial mitoses (Church 1979, Nur 1981, John 1990). Today we know that such differential heteropycnosis is due to facultative heterochromatinization, due to epigenetic changes of the X chromosome chromatin.
White's interpretation of the changes in pycnosis observed in the $\mathrm{X}$ chromosome were based on their spiral structure or differential coiling, a subject that was being actively studied in those days (Darlington 1959). Later work by White on condensation and pycnosis of sex chromosomes was interpreted more in terms of inactivation of X chromosome genetic activity and subjacent molecular mechanisms (White 1970).

Regarding neo-sex chromosomes, White's contributions were of great importance. He not only described and correctly interpreted numerous cases in Acrididae, Eumastacidae, Tettigoniidae, and Mantodea, but he produced the first comparative analyses of neosex chromosomes from an evolutionary, not merely cytological, point of view (White 1940b, 1941a,b, 1977; Castillo et al. 2010). White's permanent interest in sex chromosomes and their evolution undoubtedly stemmed from his profound interest in all aspects of animal reproduction, the underlying meiotic process, its modifications, and the fundamental role of chromosomes and meiosis in the shaping of genetic systems and organic evolution (see below). Among the fundamental components of genetic systems, genetic recombination occupies a central position.

The Orthoptera in early cytogenetics: intercourse? The crossing-over affair.-The insight of Sutton that the number of chromosomes was obviously lower than the number of characters of an organism, led to the inescapable conclusion that each chromosome must contain many hereditary factors. This posed a problem regarding Mendelian factors (genes): if many factors co-exist in the same chromosome, how could they always assort independently during gametogenesis? In fact, no sooner had Mendel's Laws been 'rediscovered' in 1900 than the first exception to the second law, that of independent assortment, was reported in 1901 by William Bateson (1861-1926): this was in the plant Matthiola, where his collaborator, Edith Saunders (1865-1945), reported a significant deviation from Mendel's second principle, for which phenomenon she proposed an erroneous hypothesis soon abandoned (Bateson et al. 1904).

In fact, the sameyear, Theodor Boveri had advanced a revolutionary idea that soon proved true: "... the traits localized in a chromosome can go independently of each other into one or the other daughter cell which would point to an exchange of parts between homologous chromosomes." [Boveri 1904, translated by Stern (1950)].

The phenomenon of genes on the same chromosome not conforming to the principle of independent assortment was later to be called 'linkage' by Morgan (1910), and the process of segmental interchange between homologous chromosomes, 'crossing over' (Morgan \& Cattell 1912, Morgan et al. 1916, Muller 1916), leading to intrachromosomal genetic recombination. Crossing over was independently discovered by the brilliant Russian geneticist Aleksandr Sergeevich Serebrovskii (1892-1948) in chickens (Fando 2008, Schwartz 2008). However, a clear explanation of the crossing over process owed much to the work of an extraordinary cytologist working alone in Belgium: Frans Alfons Ignace Maria Janssens (1863-1924) (Fig. 4).

Janssens, who was a Belgian Jesuit priest, received an excellent education in Biology at the University of Louvain, several marine biological institutes including the famous Stazione Zoologica of Naples, and the prestigious Carlsberg Institute of Copenhagen. Eventually in 1899 he succeeded the eminent cytologist J.B. Carnoy at Louvain and devoted his life to full-time research and teaching in cytology and other biological disciplines. Janssens was a gifted cytologist and was called "the microcope wizard" for his technical expertise and acute powers of observation and representation of nuclear structures. In 1909, he published a relatively short paper (for the standards of that epoch) in which he demonstrated, through 
careful examination of meiotic cells (auxocytes, as he called them) of urodelans (Batrachoseps, a plethodontid salamander), that homologous chromosomes pair, and pairs of chromatids can break at corresponding points along their length and physically exchange chromosomal material producing X-like figures that he dubbed "chiasmata"; he derived a model called the chiasmatype theory (chiasmatypie, in French) (Janssens 1909).

Morgan and his group quickly adopted this theory to explain the results of their genetic crosses in Drosophila multiple-mutant stocks. The details of crossing over were further worked out by Morgan's students, especially by Hermann Joseph Muller (1890-1967) and Alfred Henry Sturtevant (1891-1970) and were the basis for the techniques of genetic mapping. Although the chiasmatype theory was initially resisted by some geneticists, particularly the controversial German zoologist Richard Benedict Goldschmidt (1878-1958), and ironically, William Bateson (Goldschmidt 1917, Sturtevant 1917, McClung 1927, Cock 1989, Richmond \& Dietrich 2002), it proved correct.

Janssens (1924) extended his meticulous observations to insects and especially, grasshoppers in a monumental 224-page paper, which not only reinforced all previous observations of chiasmata, but has to be considered one of the XXth century's masterpieces of cytogenetic observation and illustration. The color drawings of grasshopper bivalents and chiasmata have been continually imitated in textbooks since its publication.

The chiasmatype theory was further developed by several other cytologists, chief among them, Cyril Dean Darlington (1903-1981) a former student of Bateson's at the John Innes Horticultural Institute, UK. Unlike Bateson, Darlington was an early adherent to the chromosome and chiasmatype theories, and during the following years developed his theory on the evolution of genetic systems in which chromosomes, and especially chiasmata and recombination were central to the evolutionary history of organisms (Darlington 1958). Darlington's first relevant contributions to the study of meiosis and chiasmata (before he turned almost exclusively to plants) were performed in gomphocerine grasshopper species (Chorthippus, Stauroderus), an extremely good material for cytogenetic work on male meiosis, because species of this group of genera (the 'truxaline' grasshoppers) not only have beautiful large-sized chromosomes, but also an asymmetric karyotype involving three metacentric homologous pairs of autosomes and five telocentric ones, allowing direct simultaneous comparisons of pairing and chiasma formation in both types of configurations (Darlington 1935, 1936, 1937; Darlington \& Dark 1932).

Furthermore, the study of meiosis and chiasma formation in grasshoppers helped to gain insight into a very complex evolutionary problem. Since the discovery by Morgan's group that crossing over in Drosophila occurs only in females, evidence started to accumulate that even when both sexes of an organism are chiasmate, they usually are heterochiasmate; that is, chiasma frequency and distribution are significantly different in males and females.

Normally, the heterogametic sex (males in XY/XX systems, females in $\mathrm{ZW} / \mathrm{ZZ}$ systems) shows lower chiasma frequencies than the homogametic one (Trivers 1988, Burt et al. 1991, Lenormand \& Dutheil 2005), a phenomenon called the 'Haldane-Huxley rule' (Lenormand \& Dutheil 2005) or 'two-track heredity' by Darlington (1973). In fact, it was John B.S. Haldane (1892-1964) who advanced the first hypothesis regarding this puzzle (Haldane 1922), proposing that selection against recombination between sex-determining loci in the sex chromosomes brought as a by-product, less crossing over in autosomes of the heterogametic sex. The same hypothesis was put forward by Julian Sorell Huxley (1887-1975) for his genetic data on Gammarus, a crustacean (Huxley 1928). Interestingly enough, Haldane's considerations were prompted by observations in an orthopteran, Paratettix texanus, a tetrigid.

At that time besides Drosophila, the only other insects in which serious linkage studies were being done were species of grouse locusts (Tetrigidae) by Robert K. Nabours in Kansas (Nabours 1914, 1917). It is worth noting that spermatogenesis of Tetrigidae (Tettigidae in old terminology) was already well known through studies of Mary Theresa Harman (1877-1961) and William Rees Brebner Robertson (1881-1941) (Harman 1915, 1920; Robertson 1916a,b), and although males are not achiasmate, tetrigids are characterized by extreme distal chiasma localization in autosomal bivalents, which is almost analogous to an achiasmatic situation (see below).

Nevertheless, studies on female meiosis were hampered by technical difficulties. In grasshoppers, female meiosis is arrested at an early stage of first prophase and its continuation is triggered by oviposition whence meiosis is rapidly completed. Furthermore, unlike males, each meiotic nucleus in an analyzable stage regarding chiasmata is singly isolated within a mature egg. Reliable squash techniques for the analysis of female first prometaphases and metaphases (and later stages), were only developed in the last $35 \mathrm{y}$. Thus an assessment of the Haldane-Huxley rule in grasshoppers is relatively recent (Perry \& Jones 1974, Jones et al. 1975, Henriques-Gil et al. 1986). Nevertheless, comparative studies of chiasma frequencies in both sexes of a limited number of grasshopper species did not support the Haldane-Huxley rule (Cano et al. 1987, Martí \& Bidau 1995, Grieco and Bidau 1999).

The difficulties in analyzing female meiosis are made clear in Colombo (1952) in his analysis of Anacridium aegyptium. Without an adequate protocol, only early stages up to the diffuse stage are obtained from female imagines, and this is also extremely laborious. In Church's (1974) words in a study of chiasma frequency in female Melanoplus femurrubrum: 'Obtaining 30 analysable cells in diplotene is a monumental task for the following reasons. Subsequent to pachytene of meiosis the bivalents form a typical diplotene configuration. However, this stage must be a relatively short one since it is present in only a few of the ovarioles and when it is present only three or four cells display the stage. Following this typical diplotene stage, the chromosomes elongate into a lampbrush stage and can no longer be visualised using conventional techniques'.

Indeed, in one experiment she had to sacrifice 125 females to obtain 30 diplotene cells. However, new and powerful cytological and molecular techniques applied to grasshopper chromosomes, progressively helped to gain insight on several problems associated with chiasma formation.

A matter of situation: chiasma lozalization, chiasma terminalization, terminal associations. - The use of crossing over as a means to construct genetic maps of organisms, assumed that crossovers occurred at random along paired bivalents during meiotic first prophase. However, from the early cytogenetic studies using chiasmata as physical markers of meiotic exchange, it became clear this was not always the case. Not only could one sex be totally achiasmate as in Drosophila, in many praying mantids and eumastacid grasshoppers (where no case of both sexes being achiasmate has ever been reported), but in many species chiasmata were strongly localized in more or less constant positions along bivalents. Localization, which would indicate that vast regions of the chromosomes would not recombine, usually occurs in the heterogametic sex as predicted by the Haldane-Huxley rule (Fig. 5). but unfortunately no studies on female meiosis have been performed in these cases.

Despite its genetic implications, chiasma localization is an aspect of a more general functional problem of meiosis, the relationship between pairing, synapsis and crossing over. Two different mecha- 
nisms have been described: in one, the occurrence of double strand breaks/recombination is a prerequisite for synapsis initiation; in the other, synapsis must occur for the achievement of crossing over (Viera et al. 2010a). A number of studies in grasshoppers with localized chiasmata (e.g., Stethophyma grossum, Paratettix meridionalis) have shown a relationship between incomplete synapsis and restriction of chiasma formation to synapsed regions (McClung 1927; Robertson 1931; Jones 1973; Fletcher 1977; Jones \& Wallace 1980; del Cerro et al. 1997; Viera et al. 2009, 2010b). Excellent as these observations were, they did not explain the puzzle of which event (synapsis or recombination) comes first. However, recent studies on grasshopper species with localized chiasmata, using fluorescent immunolocaliztion, have determined that the presence of mature cohesin axes at the time when double strand breaks are being produced, is a prerequisite for the onset of recombination and subsequent synapsis, at least in these species (Viera et al. 2010a,b).

Localization is opposed to terminalization. - According to Rieger et al. (1976) chiasma terminalization is 'a progressive shift between diplotene and metaphase I in the distribution of chiasmata along the arms of bivalents from their points of origin to more distal positions'. A further related problem is that represented by so-called 'terminal chisamata', terminal nonchiasmate associations, and the process of 'pseudoterminalization' (White 1959, Jones 1978, Tease \& Jones 1978, Egel 1979, John \& King 1985).

Darlington $(1929,1931,1932)$ was the firmest supporter of the concept of terminalization, which he originated, although he knew of strong cases of localization. However, since the latter seemed to be relatively scarce, Darlington considered terminalization as an almost universal process: cases of localized chiasmata that do not move as meiosis proceeds were exceptions (Darlington 1959). His views were influential for 50 years.

Nevertheless, grasshopper meiotic chromosomes helped to solve the riddle of terminalization. Chiasma comparisons at different stages in many organisms, and especially the widely studied higher plants, are complicated by the fact that at diplotene, chiasmata are difficult to differentiate from relational twists that progressively disappear towards metaphase I (Sybenga 1975). Grasshoppers do not present this problem: diplotene stages are exceptionally clear so chiasmata and twists are readily identified. From about $50 \mathrm{y}$ ago, many studies of chiasma frequency and distribution in grasshoppers failed to find evidence of terminalization (Fox 1973).

However, the definitive proof came from a series of elegant studies of bromodeoxyuridine (BrdU)-labelling of meiotic chromosomes of locusts and grasshoppers. This demonstrated unambiguously, not only that chiasmata resulted from X-type exchanges between nonsister chromatids, but also provided unequivocal demonstration that terminalization does not occur: points of exchange always coincided with chiasmata at all stages (Tease \& Jones 1978). This was also verified in mice (Kanda \& Kato 1980). Further evidence in grasshoppers came from a study in Chorthippus jucundus using C-banding and a special technique of silver impregnation to identify core-like structures within metaphase I bivalents (Santos et al. 1989)

By definition, chiasmata cannot possibly be formed in a strictly terminal position of bivalents. However, a common observation in metaphase I cells is that bivalents are frequently maintained by a terminal association that does not ressemble a chiasma. Darlington's (1932) classic explanation was that these terminal attachments of homologous chromosomes represented the full terminalization of chiasmata that had been formed in an interstitial position.

In Darlington's words describing Chorthippus meiosis: 'All the chiasmata move away from the centromeres to the ends and give terminal chiasmata; and if two are formed between one pair of arms they fuse at the ends, the penultimate association of chromatids replacing the ultimate one at the terminal chiasma' (Darlington 1959). But these associations are also clearly seen in grasshopper early diplotene bivalents where terminalization could not possibly have started.

A number of alternative explanations were put forward, all considering terminalization as a reality. Callan (1949) proposed that telomeres did not replicate until anaphase; sister telomere attachment would be essential for the integrity of the terminal association until anaphase I. White (1959) stated re Callan's hypothesis that: '...because of the way in which it was published (in a popular article), this suggestion seems not to have received the attention it deserved'. White was in sympathy with this hypothesis, but modified it, favoring telomere-telomere attachments of sister chromatids after they have been replicated, and envisioned some kind of enzymatic activity (a 'telomerease') producing their release at first anaphase.

Jones (1976), studying rye meiosis through C-banding, considered that terminal associations do not represent terminalized chiasmata. Instead, he proposed a process of pseudoterminalization that involved structural changes of the distal heterochromatic blocks present in all chromosomes, this giving the false impression of a terminal chiasma, which in fact is subterminal.

However, in a careful study of terminal associations and pseudomultiple formation involving heterochromatic blocks in the Australian grasshoppers Cryptobothrus chrysophorus and Heteropternis obscurella, John and King (1985) demonstrated that terminal associations in these species are nonchiasmate and cannot be explained by either terminalization or pseudoterminalization, although they cautiously argue that terminal associations may be of a heterogeneous nature in the case of other species. During his career, Michael White had several things to say about meiosis and chiasmata.

Chiasmata are not universal and localization is frequent: is recombination restriction a common trend?.-Although Michael White did not produce extensive analyses of chiasma frequencies in natural populations, he recognized the importance of genetic recombination (thus, chiasmata) as a fundamental component of genetic systems of species, and he realized the problems presented by the HaldaneHuxley rule (White 1965). His first involvement with chiasmata at the beginning of his career, had to do with the effects of external factors on chiasma frequency, probably influenced by studies in that direction performed in Drosophila (Plough 1917, 1921, 1924). His first paper on the subject dealt with the experimental effect of different rearing temperatures on chiasma frequency and distribution in Schistocerca gregaria, Locusta migratoria and Stenobothrus (= Chorthippus) parallelus. He interpreted his results in terms of 'interference', a known genetic phenomenon: higher temperatures would reduce the interference distance, and discussed his hypothesis in relation with to the chiasmatype and classical theories of chiasma formation.

This pioneer study was the basis for further and more elaborate analyses of the effects of temperature on crossing over in grasshoppers (Henderson 1962, 1988; Church 1974). It was demonstrated for example, that temperature may affect chiasma frequency in different forms, depending on the moment of the treatment, i.e., in spermatogonia or after the completion of premeiotic DNA synthesis (Henderson 1988). Another factor studied by White, was the influence of X-rays on crossing over (White 1937).

Two other problems relating chiasmata and crossing over, less experimental but extremely interesting, motivated a number of other White studies: one was the phenomenon of chiasma localization, which has also a direct relation with the process of synapsis. Although this problem is only now starting to be disentangled (see Viera et al. 
2010 in this same issue and references therein), White produced two pioneering papers on male meiosis of species with strong localization, one of which was intensively studied in the following years by several authors (White 1936, 1954; Viera et al. 2010). Although White's hypotheses about the causes of localization (for example that chiasmata formed preferentially in the boundaries between hetero- and euchromatin) were later disproved, his observations were fundamental in drawing attention to a problem that asked for a solution, that is, the mechanism and adaptive nature of localization in widely different grasshopper species, and the situation of chiasmata in female meiosis (White 1954, 1964).

White was of the idea that some degree of localization is almost universal, implying that restriction of recombination, at least in one sex (usually the heterogametic one), should be adaptive. This observation is very relevant because chromosomal rearrangements, one of White's lifetime interests, have deep impact on recombination, and this effect has been repeatedly involved in models of chromosomal polymorphism and speciation (White 1958): 'The significance of chromosomal rearrangements of various kinds in the adaptive polymorphism of many animal and plant species depends to a large extent on their effects on crossing over' (White \& Morley 1955). In this sense, he was always fascinated by 'anomalous' types of meiosis, especially those in which one of the sexes is achiasmate.

In fact, White (1938) was the first to describe achiasmatic meiosis in a mantid, Callimantis antillarum and later in other African and Australian genera, plus another type of peculiar meiosis which he called 'cryptochiasmatic' (1941a, 1965b, 1975a). Mantids and their male meiotic process were of profound interest to White because of their wide variation in diploid numbers, their varied and complex sex-determining mechanisms, and because the existence of male achiasmate meiosis posed problems to the mechanism that maintained the integrity of bivalents to allow normal segregation (White 1977, Wolf 1994).

He had an excellent opportunity to analyze these issues in a group of orthopterans closely related to the Australian Morabinae, the subfamily of Eumastacidae in which White produced his most extensive and relevant work on evolutionary cytogenetics. In a comprehensive study of 33 species of the Eumastacid subfamilies Thericleinae and Euschmidtiinae from Africa (White 1965a), a number of meiotic peculiarities unique to Thericleinae were disclosed for the first time: in the majority of species, classic diplotene and diakinesis are omitted in male meiosis, and chiasmata only appear at early or midmetaphase I; the latter species are 'cryptochiasmate'. Also, three Thericles species are clearly achiasmate, while oocyte metaphase I (obtained by the sectioning technique) shows classical chiasmata. But sex and meiosis (or the lack of it) posed further challenges to orthopteran cytogeneticists.

When the battle of the sexes has a winner: parthenogenesis. - The vast majority of orthopteroid insects reproduce sexually (White 1951a, 1975a, 1977; Hewitt 1979). However, a number of species do so parthenogenetically. The original definition of parthenogenesis was by Richard Owen (1849): 'procreation without the immediate influence of a male'. Since a number of forms of reproduction distinct from the usual sexual one are frequently included within this concept, several definitions of parthenogenesis have been put forward (Mittwoch 1978). A useful definition is: 'the production of an embryo from a female gamete without the participation [or, without ant genetic contribution] of a male gamete, with or without eventual development into an adult' (Rieger et al. 1976). According to the mode of sex determination, parthenogenesis is classified in: arrhenotoky (unfertilized eggs develop into males, fertilized ones into females), deuterotoky (unfertilized eggs develop into either sex), and thelytoky (unfertilized eggs develop into females) (Mittwoch 1978, de Meeús et al. 2007).

In orthopteroid insects, thelytoky is the sole known form of parthenogenesis (White 1977). However, the mechanisms involved in the development of the unfertilized egg are varied. In ameiotic (apomictic) thelytoky, eggs are produced mitotically and this implies, barring mutation, strict clonality; in meiotic (automictic) thelytoky, eggs are produced by meiosis, but the ploidy of eggs is restored by any of several mechanisms (White 1977, Mittwoch 1978, Normark 2003). Automictic thelythoky is common in stick-insects and several genera have been well studied in this respect, such as Carausius, Bacillus, Clitarchus, Sypyloidea and Timema (Koch et al. 1972, Kearney 2003, Marescalchi \& Scali 2003, Schwander \& Crespi 2008, Morgan-Richards et al. 2010). An old case that is also relatively well known is that of Pycnoscelus surinamensis, a cockroach with ameiotic thelytoky where eggs are produced through two maturation divisions of equational type (Matthey 1945, Roth \& Cohen 1968). At least one mantid, Brunneria borealis, is parthenogenetic (White 1948).

In the Orthoptera Saltatoria occasional thelytoky (tychoparthenogenesis) has been reported in several species of otherwise sexual insects (see Pardo et al. 1995). The earlier examples are the studies on Apotettix and Paratettix grouse locusts by Nabours (1919) and Robertson $(1930,1931)$. Cases of obligatory thelytoky are however, very rare. There are some thelytokous cavernicolous crickets but their cytology is unknown (White 1977, 1978). Within the Tettigoniidae three species, Saga pedo, Poecilimon intermedius, and Xiphidiopsis lita are thelytokous (White 1977, 1978), but the mode of parthenogensis is only known for $S$. pedo, which is tetraploid and ameiotic, their eggs undergoing one maturation equational division (Matthey 1941, Dutrillaux et al. 2009).

The only other case and the most impressive and well-studied one, is that of the Australian morabine Warramaba virgo, discovered by White (1962) in Eastern Australia feeding on Acacia (mulga) shrubs. A year later, White et al. (1963a) published the first of a long series of papers about the cytogenetics and evolution of this extraordinary grasshopper. In this paper, the species was provisionally described as Moraba virgo, and it was demonstrated that thelytoky was meiotic through careful observation of oocyte meiosis in sectioned material. Furthermore, since $W$. virgo has 15 somatic chromosomes and the meiotic cells exhibit 15 bivalents, it was suggested that restoration of the diploid condition occurs by a premeiotic doubling of chromosomes, followed by a normal meiosis (White et al. 1963a).

One of the most interesting problems posed by the study of $W$. virgo chromosomes was that the karyotype was heterozygous for several structural rearrangements and late-replicating regions (White \& Webb 1968, Webb \& White 1975). The authors explained this unique re-arranged karyotype (or karyotypes, since there were small vatiations between different populations) as the result of chromosomal mutations accumulated since the onset of parthenogenetic reproduction (White et al. 1977).

However, since the discovery of $W$. virgo and the widening of its geographic distribution, new related bisexual species had been found in Western Australia, as well as new W. virgo populations. This led Godffrey M. Hewitt (1975) to propose a new model for the origin of the species and its unusual karyotype. Considering that many parthenogenetic forms have arisen through hybridization (de Meeûs et al. 2007), he proposed that $W$. virgo had been originated in Western Australia as a hybrid between species P169 and P196 (or very similar ancestors), with subsequent acquisition of premeiotic doubling and parthenogenesis (Hewitt 1975). The hypothesis explained the standard W. virgo karyotype, the structural heterozygosity and the late-replicating patterns. The deviations from the standard karyotype could be explained by minor independent 


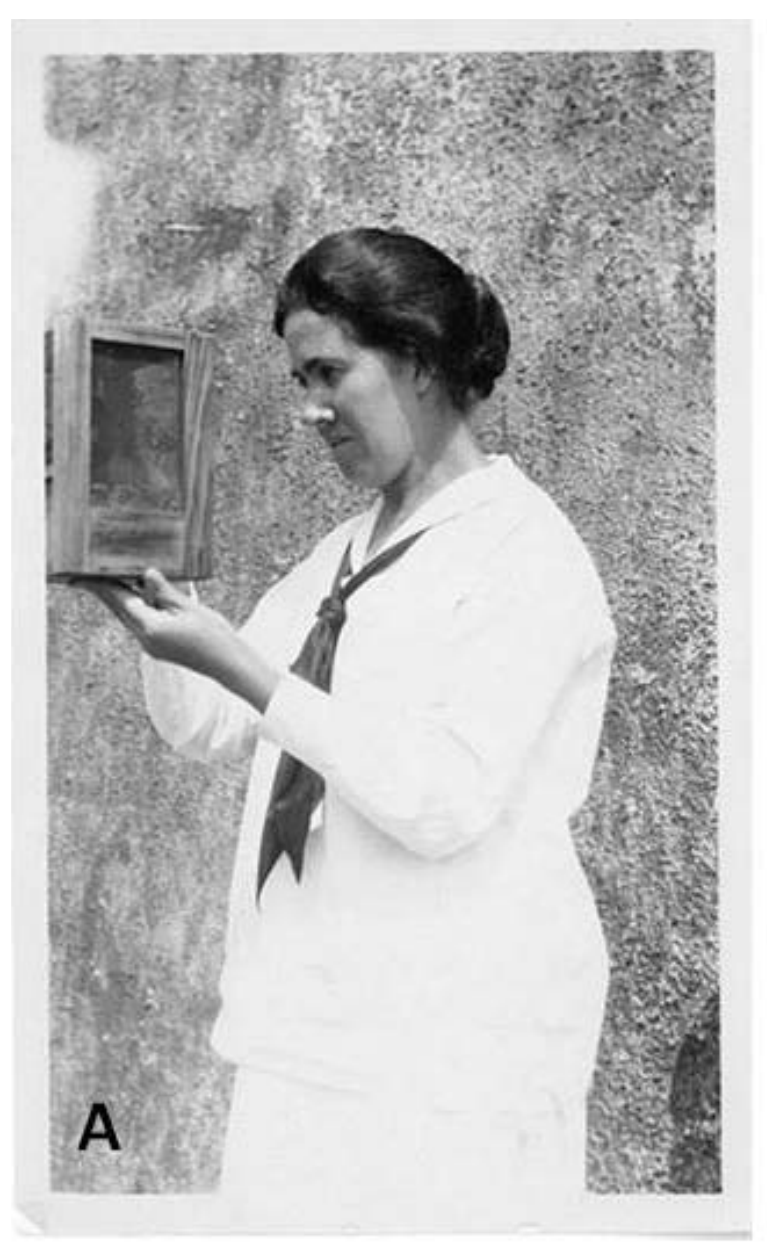

Fig. 3. Estrella Eleanor Carothers and the chromosomal basis of Mendel's Laws. A. Carothers holding a specimen cage; B. Plate I from her 1931 paper (Carothers 1931, Biological Bulletin 61: 324-329.); the plate shows male spermatogonial and meiotic divisions of Trimerotropis citrina. Several heteromorphic autosomal bivalents are shown.

mutational changes.

It is a tribute to Michael White's scientific honesty and open mind that he promptly started to test predictions of Hewitt's model by experimental hybridization between $P 169$ and P196, which produced 'synthetic virgo', and by chromosome banding, DNA replication patterns, repeated sequences, and RNA ribosomal cistrons (White et al. 1977; 1978a,b; 1979; 1980; 1981; 1982). The results quickly supported the hybrid hypothesis (including the possibility of more than one hybridization event) which was immediately adopted by White.

White's studies in $W$. virgo constitue a landmark in insect evolutionary cytogenetics and today this species is a classical model for the studies of the causes and consequences of parthenogenesis (Kearney 2003, Kearney \& Mousalli 2003).

It is interesting that Michael White, with his encyclopedical knowledge of cytogenetics, did not concentrate on B chromosomes, a common form of karyotype variation in grasshoppers.

B chromosomes: invasion of the genomic parasites. - B chromosomes are selfish genetic entities found in numerous animal and plant species, engaged in a continuous conflict with the standard A-genome (Camacho et al. 2000). A simple definition has been given by Jones (1995): ' ...dispensable supernumeraries which do not recombine with any members of the basic A chromosome set and which have irregular and non-Mendelian modes of inheritance'. Older definitions included their genetic inertness, but there is growing evidence that some $\mathrm{B}$ chromosomes carry active genes, despite the fact that once they arise, probably from A chromosomes, they undergo a process of genetic degeneration analogous to that of the $\mathrm{Y}$ or $\mathrm{W}$ sex chromosomes. These genes include rDNA sequences in orthopterans, dipterans, amphibians and flowering plants, genes conferring resistance to rust in oat, to antibiotics in a fungus, and even an active proto-oncogene in the silver fox and the raccoon dog (Green 1990, Camacho et al. 2000, Bidau et al. 2004, Basheva et al. 2010).

As with so many intriguing problems in cytogenetics, research on B chromosomes has benefited enormously from studies in grasshoppers and other Orthoptera (Hewitt 1973). Although the term 'B chromosome' was coined by Randolph (1928) for maize supernumeraries, their discovery and first formal study was performed by Nettie Maria Stevens (1861-1912), the extraordinary Bryn Mawr cytologist who also discovered the Y-chromosome of insects (Castillo et al. 2010). She observed and described Bs and their erratic meiotic behavior in chrysomelid beetles of the genus Diabrotica (Stevens 1908b, 1912b). Also in 1912, she published the first account of B chromosomes in Orthoptera in an unidentified species of the cave cricket Ceuthophilus (Raphidophoridae), analyzing their male meiotic behavior in relation to the autosomes and X chromosomes (Stevens 1908). It is worth noting that Stevens suggested a possible relationship between the Bs and the $\mathrm{X}$, which is presently considered as one of the possible origins of Bs through polysomy and degeneration (Hewitt 1976, Camacho et al. 2000). Although B chromosomes were occasionally detected in cy- 

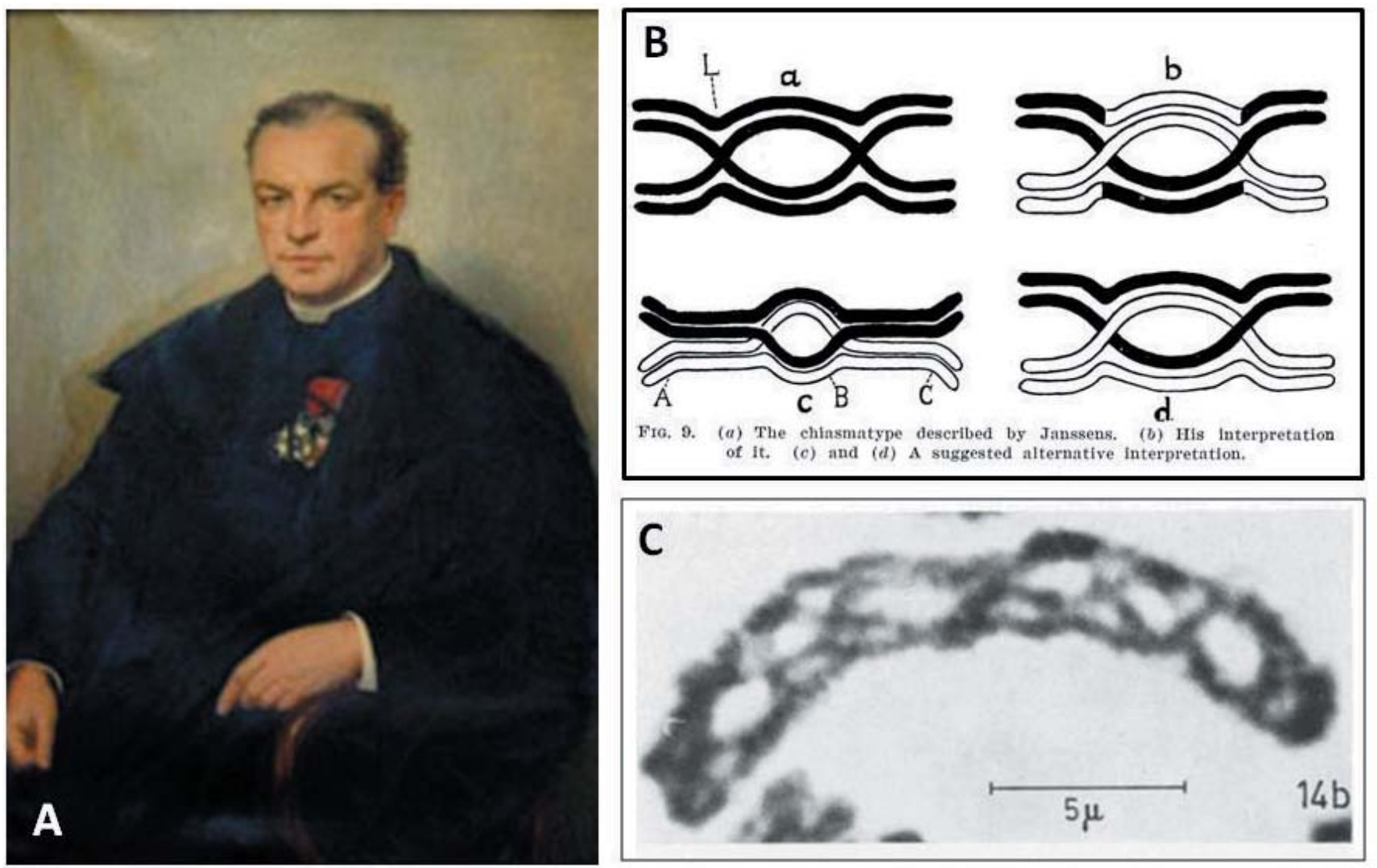

Fig. 4. Frans Alfons Janssens and the chiasmatype theory of crossing-over. A. Janssens in his priestly robes; B. Hermann Joseph Muller's explanation of the chiasmatype theory and one alternative hypothesis (Muller 1916, Am. Nat. 50: 284-305.); C. The largest autosomal bivalent (metacentric) of the tettigoniid Metrioptera saussureana, showing eight chiasmata (from John and Hewitt 1968; Chromosoma 25: 40-74.).

togenetic studies of other orthopteran species [for example, Sáez (1930) described the first case of Bs in a Neotropical grasshopper, Orphulella punctata], they only started to gain relevance after White's large scale population studies in the North American Oedipodinae (White 1949, 1951 b, c).

Population studies revealed that B chromosomes form natural polymorphisms, and that their frequencies in the wild vary widely between populations. This is of interest for reasons discussed below. White reported Bs in several species of Trimerotropis, in particular T. sparsa, a species distributed in western North America. He found polymorphisms for two types of B chromosomes, acrocentric and metacentric, whose frequencies were very different in eastern and western populations. Both types of Bs seemed to be nonhomologous, the acrocentric type always forming, when in double dose, a chiasmate bivalent that co-oriented along with the autosomes in metaphase I, while both arms of the metacentric B paired and formed a chiasma between their euchromatic ends (White 1951b). This was the first report of what White correctly interpreted as a B isochromosome, a type of supernumerary later found in other grasshopper species (Hewitt 1973; Camacho et al. 1981; Confalonieri \& Bidau 1985; López-León et al. 1993; Santos et al. 1993; Bakkali et al. 1999; Grieco \& Bidau 1999, 2000). It was demonstrated that the iso-B of Metaleptea brevicornis is dicentric and its anomalous meiotic behavior induces the production of very high frequencies of abnormal sperm (Grieco \& Bidau 2000).

Following White's pioneering studies, research on grasshopper B chromosomes increased substantially, not only with respect to their dynamics and role in natural populations, but also regarding their origin, transmission mechanisms, internal (molecular) structure, and conflict with the A genome.

Owing to the extent and special characteristics of their B chromosomes, some grasshopper species constitute exceptional model organisms for studies of supernumeraries. The gomphocerine Myrmeleotettix maculatus and the eyprepocnemidine Eyprepocnemis plorans are two such models. These species allowed a more profound understanding of B-chromosome meiotic behavior, including mechanisms of elimination and accumulation through meiotic drive, B chromosome structure in terms of molecular composition, effects on carriers at the endo- and exophenotypic levels, distribution in natural populations, including cases of clinal variation, and the relationships of Bs with the A genome and their evolution through genomic conflict, especially in E. plorans (Hewitt 1973a,b,c, 1979; Jones 1991; Camacho et al. 2000, 2004; Manrique-Poyato et al. 2006; Teruel et al. 2009; Bakkali et al. 2010).

From heteromorphism to heterochromatin: supernumerarysegments. -A very common form of chromosomal variation in natural populations of most grasshopper species is that produced by supernumerary heterochromatic segments (John \& Hewitt 1966, John 1973, Hewitt 1979). Segments, as B chromosomes, are dispensable and frequently occur in the smallest (S) telocentric chromosomes of the karyotype, but may be present in any element (John 1973). In some cases, the segment may be several times larger than the chromosome in which it occurs, as in Leptysma argentina (Bidau \& Hasson 1984). Segments are usually C-band, although euchromatic segments are known (Camacho et al. 1984, John \& King 1985, 


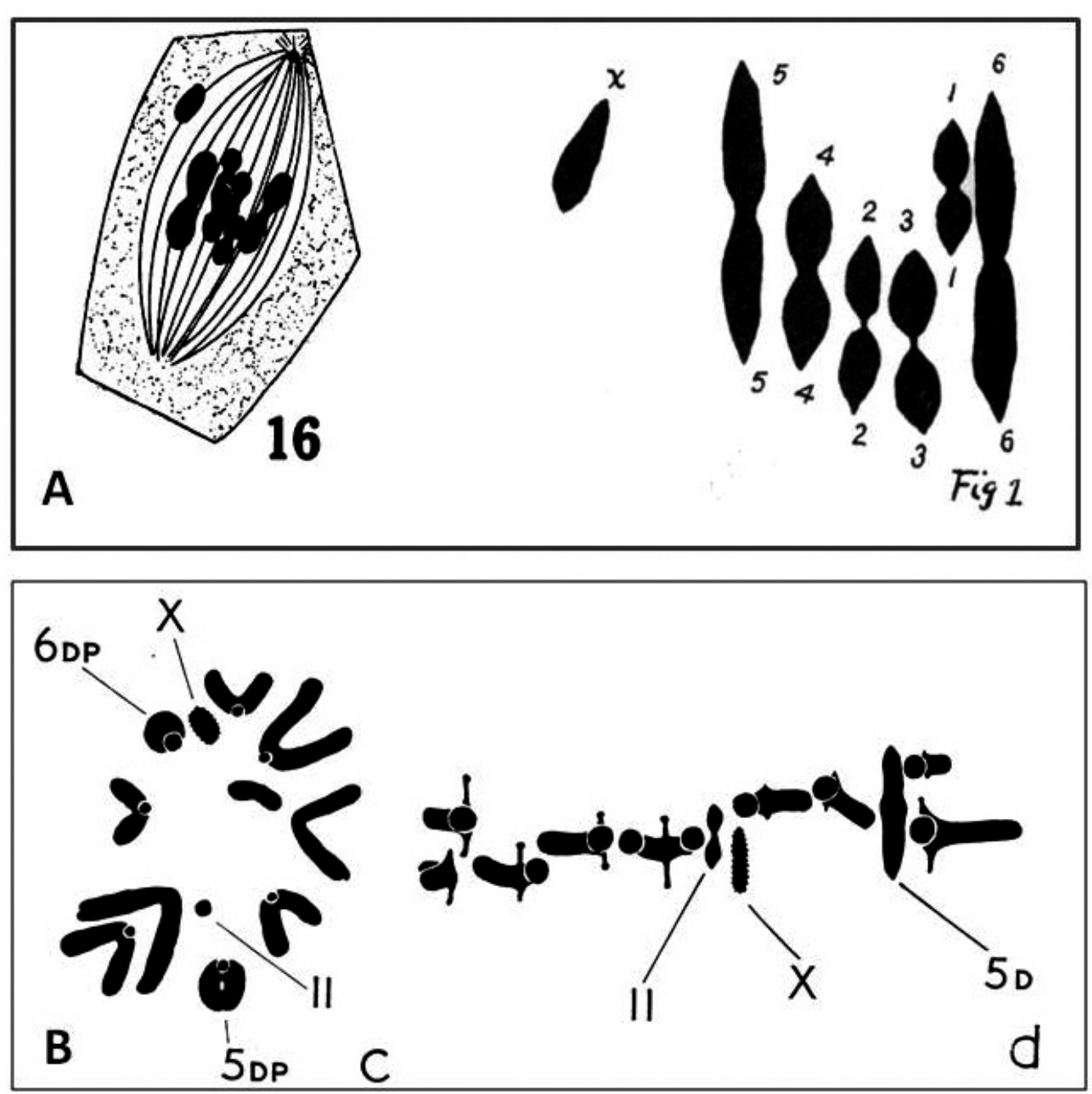

Fig. 5. Chiasma localization. A. Extreme distal chiasma localization in male Paratettixleuconothus-leucothorax (left) and Apotettix eurycephalus (right) (Tetrigidae) (from Harman 1915, Biological Bulletin 29: 262277, and Nabours and Robertson 1933, Proceedings of the National Academy of Sciences, USA 19: 234-239 respectively.) B. Extreme proximal chiasma localization in male Bryodema tuberculata first metaphases (left, polar view; right, equatorial view) (from White 1954, Evolution 8: 350-358).

A

Fig 1

Camacho \& Cabrero 1987) and some species show extensive and amazing variation for heterochromatic segments and bands, both in polymorphic and polytypic forms (John \& King 1977, 1982, John et al. 1986),

Heterozygous segments produce heteromorphic meiotic bivalents which were extremely useful in the early studies of meiotic segregation that allowed Eleanor Carothers to demonstrate the physical basis of Mendel's laws (see above). However, since segments may be proximal, interstitial, distal or extrinsic (John 1973, Hewitt 1979), chiasma formation in different locations with respect to the segment and the centromere determine that segregation of the inequality may be reductional or equational at first meiosis. This situation as stated before, produced some confusion about the ordering of meiotic events.

A number of early studies reported supernumerary segments in grasshoppers (White 1951a, and references therein). In fact the meticulous study of male meiosis in Phrynotettix magnus by Wenrich (1916) presented fine images of heteromorphic bivalents in which heteropycnotic segments and their relation to chiasmata are shown at different states.

However, the first study of segments at a populational level, was that of White and Nickerson (1951) in a rare gomphocerine North American grasshopper, Pediosicirtes (now Acrolophitus) nevadensis. White (1940) had always been interested in heterochromatin. In the mentioned study a very small population of this species showed high frequencies of polymorphic supernumerary segments (apparently of the extrinsic type) in the three S autosomal pairs, and this was observed in a reduced sample of nine males. The authors discussed this high degree of polymorphism in such a small sample and population of a seemingly relict species, and considered a number of possibilities, one of which was that heterozygosis for segments was maintained because they were adaptive (White $\&$ Nickerson 1951). Although the authors studied chiasma frequencies, they could not compare between different individuals and karyotypes. This could have been useful, since it is now known that supernumerary segments usually affect chiasma frequency, and distribution of the carrier chromosomes (Camacho et al. 1984; Navas-Castillo et al. 1985, 1987; Suja et al. 1994); but in many cases their effect is interchromosomal, modifying chiasma frequency (usually increasing it, but sometimes producing a decrease) and/or distribution of the rest of the complement (Hewitt 1979, Santos 1993, Rodríguez-Iñigo et al. 1998).

Although practically no studies of effects of segments have been made in females, Santos (1993) found that in Euchorthippus pulvinatus heterochromatic segments increase chiasma frequency in males, but have no effect in females. Other reported effects of supernumerary segments refer to their possible role in maintaining bivalent integrity before segregation through persistent, nonchiasmate terminal associations, and the formation of pseudomultiples and nonhomologous associations (John 1973, Church 1974, John \& King 1985, Rodríguez-Iñigo 1998). The most plausible hypothesis about the maintenance of natural polymorphisms of segments is that they serve as regulators of recombination, as proposed for most polymorphic chromosomal rearrangements (Bidau \& Martí 2002, 2005). 

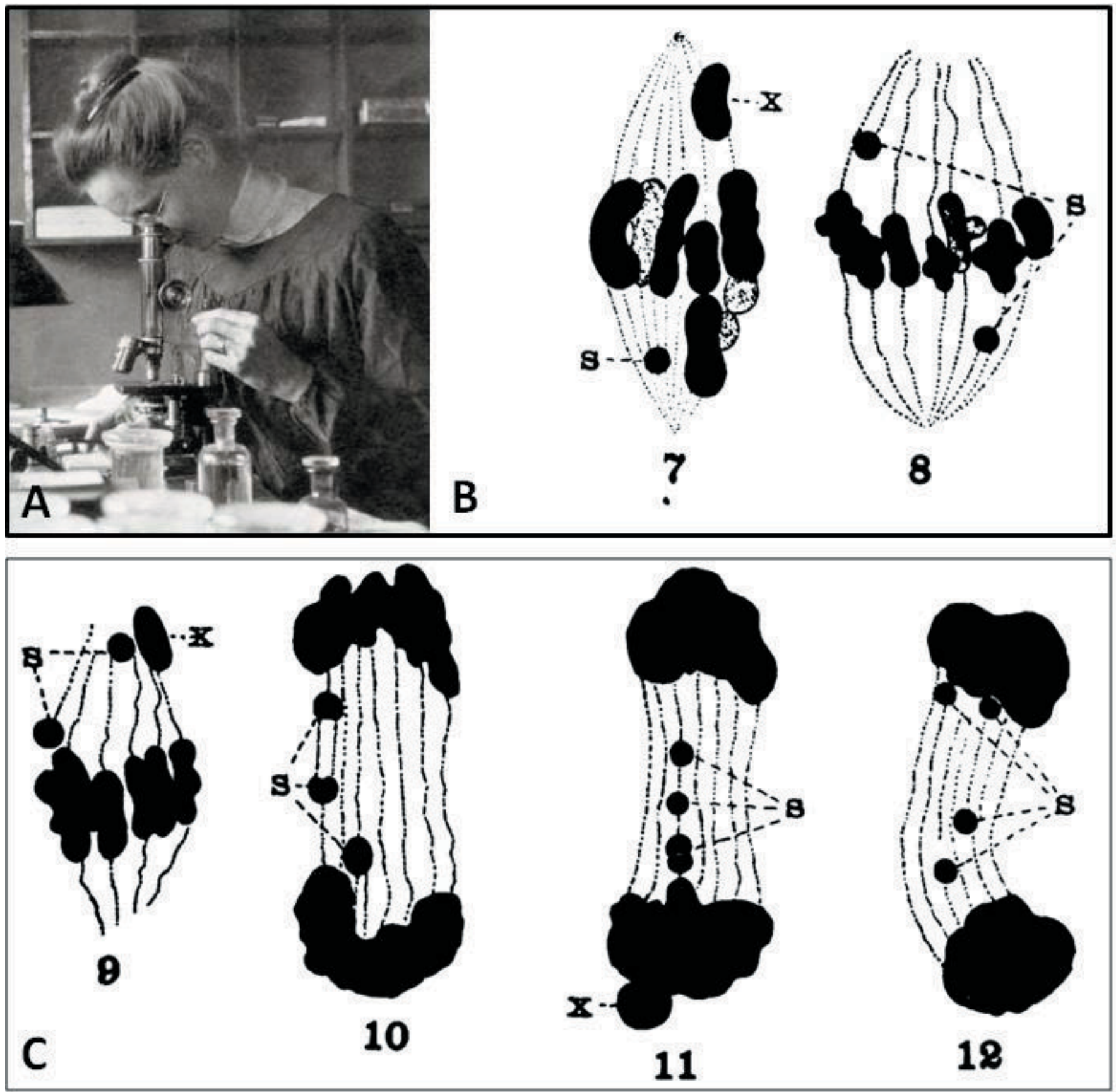

Fig. 6. The discovery of B chromosomes in Orthoptera. A. Nettie Maria Stevens at her microscope. B. Two male first metaphases of Ceuthophilus sp. showing one and two B chromosomes (s), respectively; C. A first metaphase of Ceuthophilus sp. with two B chromosomes (s) migrating precociously to the same pole, and three first telophases with lagging Bs and B-chromatids (s) (from Stevens 1912, Biological Bulletin 22: 219-230).

As for the nature and origin of supernumerary segments, the most accepted hypothesis is that they result from amplification of pre-existing regions of the chromosomes (John 1973, Camacho \& Cabrero 1987) and consist usually of tandem repeats and in some cases, interstitial telomeric sequences (John et al. 1987, LópezFernández et al. 2004). In a few cases, the segment resulted from a translocation involving the megameric (usually heterochromatic, Carlson 1936) bivalent (Camachoet al. 1986). Finally, Camacho and Cabrero (1987) proposed two other hypotheses to explain special cases: euchromatinization of previously heterochromatic regions, and in the case of euchromatic segments in the megameric bivalent of some gomphocerines, they could be relicts of a euchromatic region that formed part of the ancestral megameric

Classic observations of grasshopper chromosomes were based on fixed material, but could they be observed 'live'?

Real life: chromosomes in motion. - The first observations on grasshopper chromosomes (and those of other organisms) were, of course, done in fixed and sectioned somatic and gonadal tissues. However, different fixation and staining techniques produce different results, and not infrequently, artifacts. Thus, in the beginnings of cytogenetics, many structures observed in normal fixed preparations were misinterpreted or even their existence doubted. That was the case for spindle fibers, the fundamental structures that, through their 


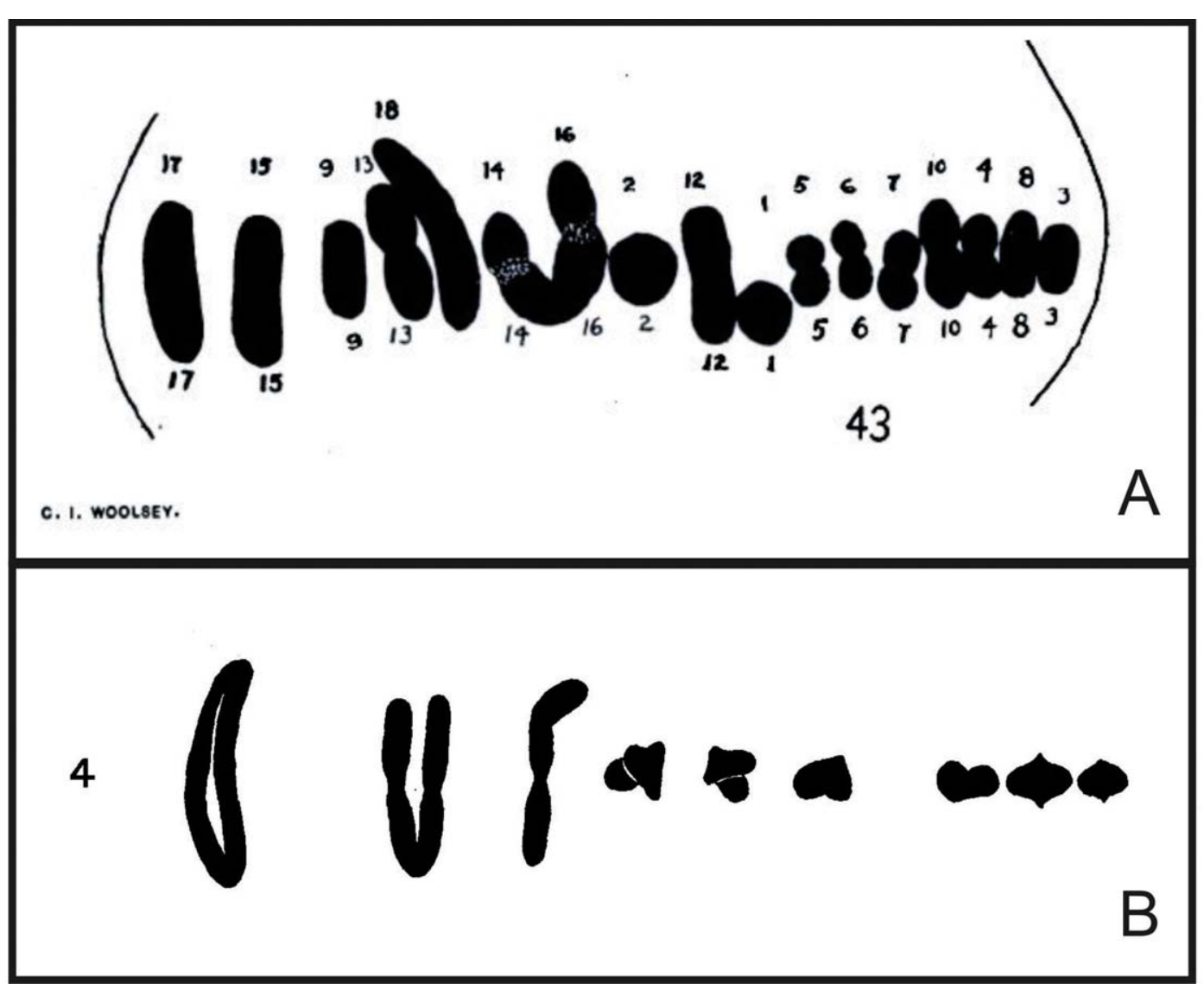

Fig. 7. The first centric fusion trivalents described. A. Male metaphase I of Jamaicana subguttata showing a fusion trivalent (14-14.16$16)$; the $\mathrm{X}$ chromosome is the large univalent on the far left (from Woolsey, 1915, Biological Bulletin 28: 163-186); B. Male metaphase I configurations of Hesperotettix viridis ordered by decreasing size; this individual was homozygous for a centric fusion (far left), heterozygous for a centric fusion (V-shaped trivalent), and carried a neo-XY sex bivalent (third configuration from the left) (from Mc Clung, 1916, Journal of Morphology 29: 181-264).

relationships to chromosomes in dividing cells, allow chromosome movements in mitosis and meiosis. Although the spindle was known from the early days of cytology, it was difficult to see except as a fusiform clear area devoid of mitochondria and other organelles (Ault 1996). Although spindle fibers were occasionally seen, they were considered artifacts, and the spindle itself, a nonfibrous gel; the controversy lasted until 1953. This is not to say that excellent studies of spindle fibers were not performed in fixed orthopteran material (e.g., Carothers 1936). However, it was the study of the large living cells of Orthoptera and their micromanipulation, that helped resolve this problem and furthermore, disentangle the complex processes of chromosome attachment to the spindle, and their congression, orientation and segregation in mitosis and meiosis.

Belař (1929), studying living spermatocytes of Chorthippus lineatus, showed that hypertonicity produced transversal shrinkage, and bending and splitting of the spindle. Bent spindles showed fibrous structure when fixed, and fibers seemed to be closer together in the bent region. Also, splits were always parallel to the longitudinal axis. All these features suggested a longitudinal structure of the spindle. Studies of Schmidt (1939) using polarized light also indicated a longitudinal structure. Ris (1949) further reported spindle fibers and attachment of chromosomes in living meiotic cells of Chortophaga viridifasciata and four other grasshopper species. However, direct unambiguous observation of spindle fibers was only possible through improvements of polarized light microscopy by S. Inoué (1953) who, with his newly developed microscope, observed spindle fibers corresponding to those in fixed cells in spermatocytes of the grasshoppers Dissosteira, Melanoplus, and Chortophaga, and also the dipteran Drosophila. This was the definitive proof that fibers were not artifacts.

Regarding chromosome movements, living orthopteran cells also have a long and fruitful history. The first chromosome micromanipulation study of living spermatocytes of grasshoppers (e.g.,
Dissosteira carolina), crickets, a cockroach, and the squash bug (Anasa tristis) was performed by Kite and Chambers (1914) and Chambers (1917). They easily removed intact spindles and also isolated individual chromosomes with attached spindle fibers, a notable feat for the 'crude' methods employed. More sophisticated and less destructive methods were slowly developed and in 1942, Carlson studied embryonic neuroblasts of Chortophaga (Carlson 1942), perforating living cells with a microneedle to manipulate the spindle and associated chromosomes; he determined that the latter were mechanically attached to the spindle, which was a semisolid longitudinal structure, through their kinetochores from prophase through late anaphase. Further micromanipulative work on living cells was prompted by the development of the piezoelectric micromanipulator (Ellis 1962, Ault 1996).

The new technology allowed a series of extraordinarily elegant experiments on living spermatocytes of grasshoppers, especially by R. Bruce Nicklas and his colleagues and disciples, originally using as a model Melanoplus differentials and later extended to other grasshopper species, such as Trimerotropis maritima and Eyprepocnemis plorans. These studies allowed us to gain deep knowledge on such important problems as: attachment of kinetochores to the spindle, kinetochore orientation and re-orientation during prometaphase I and metaphase I, in vivo orientation and segregation of the X chromosome, autosomal univalents, multiple chromosomal configurations (e.g., translocations and Robertsonian fusions, and B chromosomes, including an exceptional case of a B chromosome translocated to an autosome) (Nicklas 1961; Nicklas \& Staehly 1967; Henderson \& Koch 1970; Wise \& Rickards 1977; Arana \& Nicklas 1992; Rebollo \& Arana 1998, 2000; Granado et al. 2004).

The possibility of studying living meiotic configurations was also relevant to the understanding of the meiotic behavior of multiple chromosome configurations. 
When grasshoppers began to show bizarre meiotic configurations.-The chromosomal theory of heredity and the contributions of orthopteran cytology were central for the establishment of the individuality of chromosomes and the stability of the karyotype. However even in the earliest period of cytogenetics, it became clear that both principles were somewhat relative, leading in due time to our present knowledge of the genome as a dynamic entity in time and space.

It was evident from the first studies of orthopteran cytology that homologous chromosomes may be heteromorphic (due to heterochromatin additions or deletions as we know today), and the standard diploid number may vary due to B chromosomes (Carrol 1920). Also, sex chromosomes and autosomes or autosomes among themselves, could become 'fused' (McClung 1905, 1916; Robertson 1916b). Indeed, Robertson (1916b) was the first to discuss centric fusions (later called Robertsonian translocations in his honor) in grasshoppers in taxonomic and evolutionary terms, from which the 'Robertson Law' (the variation of diploid number without modification of the number of chromosome arms) was derived: 'Variations which have occurred in the Acrididae and which seem to be of a permanent nature are the fusion of non-homologous autosomes to form compound chromosomes as in the species of the genus Chorthippus. That these are variations is to be inferred from the fact that about nine-tenths of the genera of the twenty-three-chromosome grasshoppers do not possess these $V^{\prime}$ s, while in one-tenth, and especially this one genus Chorthippus, the species so far described (5) all show this variation (Robertson 1916b).

The fusion process was later correctly interpreted as a special form of translocation (Coleman 1947, John \& Hewitt 1968, White 1977). The possibility of 'splitting' (fission) of chromosomes had also been proposed for other insect groups (Payne 1909).

It was Carrie I. Woolsey, Robertson's student at Kansas, who first described a probable structural polymorphism in a grasshopper (Woolsey 1915). She studied three species of the tettigoniid genus Jamaicana (Pseudophyllinae) which differed for fixed fusions, but in one of them, J. subguttata, (Fig. 7) she found an individual that was heterozygous for a fusion, thus describing the first fusion trivalent in the history of cytogenetics. She also analyzed its segregation and advanced some ideas on nuclear architecture influencing the production of the rearrangement. Robertsonian translocations are frequent as fixed differences between species or races, but very rare in a polymorphic state (see below); thus Woolsey's discovery was of great importance, although the species was never studied again. The second case of fusion polymorphism was described a year later by McClung (1916) in Hesperotettix viridis.

It soon became obvious that reciprocal translocations and inversions occurred spontaneously in natural populations of grasshoppers (Carothers 1931; White 1940c, 1963; Coleman 1947; Bidau \& Hasson 1984), and that such structural mutations could also be induced in grasshoppers by mutagenic agents such as X-rays, a field in which Michael White was also a pioneer (Nabours \& Robertson 1933; White 1935, 1937a,b; Carlson 1941a,b). However, although spontaneous and induced rearrangements were of interest on purely genetic and cytogenetic grounds, it was their role as polymorphisms in natural populations, their mode of fixation, and their possible role as postmating isolating mechanisms that attracted the interest of grasshopper cytologists.

Orthopterans, and especially acridids, were ideal subjects for populational studies of this kind because of the ease of studying the effects of re-arrangements on meiosis and fertility. The first large-scale population studies on grasshopper chromosomal polymorphisms were performed with North American Oedipodinae of the genera Trimerotropis and Circotettix, a subject reviewed in this same issue by Guzmán and Confalonieri (2010).
Again, Michael White pioneered these studies in a series of investigations that set the pace for a lifetime career devoted to the understanding of the role of chromosomal rearrangements in microevolution and speciation (White 1949, 1951b, c). From the start, White's thinking about these problems was clearly populational: 'The existence of this type of polymorphism in certain species of Trimerotropis and Circotettix has been known since the work of Carothers [...] but has never received the attention which it deserves and has not been properly understood from the standpoint of the population-dynamics of these species.' (White 1951b). His studies on these genera led White to propose taxonomic and evolutionary hypotheses, based solely on cytology and geographic distribution, that have been recently supported by modern molecular methods (Guzmán \& Confalonieri 2010).

White's fundamental contributions to population and evolutionary cytogenetics and the role of chromosome change came from his extraordinary research in the morabine grasshoppers of Australia, a work in which he was much benefited by his interaction with several notable collaborators, especially Kenneth Hedley Lewis Key (1911-2002), the eminent Australian orthopterist (Peacock \& Dennis 2010). Besides the Warramaba virgo model discussed above, two other major lines of research were developed by White: the analysis of the chromosomal polymorphisms of Keyacris (formerly Moraba) scurra, and the study of chromosomal diversification and its evolutionary implications in the Vandiemenella (formerly Moraba) viatica group of species. Both research projects showed the typical and fruitful mixture of White's descriptive, experimental and analytical work.

In Keyacris scurra, a species inhabiting southeastern Australia, the main focus of White's work in a series of papers published between 1957 and 1963 (Peacock \& Dennis 2010), were the species' chromosomal races and especially the pericentric inversion polymorphisms which showed positive heterosis within populations, but negative heterosis in hybrids. The latter was considered by White as a plausible mechanism of race formation and this hypothesis probably laid the foundations of White's later ideas on speciation mediated by chromosomal change. The impressive work on the inversion system of $K$. scurra was the basis for many later population cytogenetic studies in other grasshoppers; it radically changed the then somewhat simplistic view on the maintenance and role of chromosomal polymorphisms in nature; it stressed the importance of the recombination modifications these polymorphisms produce in the evolutionary dynamics of species (White 1957, 1958; White \& Lewontin 1960; White et al. 1963b).

Research on the $V$. viatica group of species was central to consolidate White's ideas on chromosomal speciation and eventually led to his formulation of the stasipatric model (White 1968, 1978), applicable to organisms of low vagility in which chromosomal rearrangements play a central role in speciation without geographic isolation. In this model, speciation could occur within the range of a species if chromosomal re-arrangements became fixed in an internal deme and further expanded through the range of the parent species, generating a narrow hybrid zone and displacing the parental form to the periphery of the distribution (White 1969, 1978). Of course, the chromosome re-arrangements had to be underdominant in hybrids and this is one of the major drawbacks of most chromosomal speciation models (Ayala \& Coluzzi 2005, Butlin 2005).

However despite criticisms, White's ideas on chromosomes, polymorphism and speciation were extremely influential in studies of otherwell-studied grasshopper models, such as the Australian Caledia captiva that has two chromosomal races or subspecies ('Moreton' and 'Torresian') differing for fixed pericentric inversions, which form narrow hybrid zones originally attributed to hybrid inferiority 
(Shaw 1976; Shaw et al. 1980, 1987; Marchant et al. 1988; Arnold et al. 1999), and the South American Dichroplus pratensis, where a very complex system of polymorphic Robertsonian fusions with monobrachial homologies generate recombination repatternings and hybrid zones with reduction of gene flow (Bidau 1990; Bidau \& Martí 1995, 2002, 2004, 2005; Chiappero et al. 2004; Miño et al. 2010).

Chromosomal models of speciation flourished 30 years ago, but then became somewhat discredited due to theoretical population genetic considerations. However, recent years have witnessed a revival of chromosomal speciation in the form of 'recombinational' models, which put more emphasis, not on hybrid underdominance, but on the role of the effects of re-arrangements on genetic recombination to prevent gene flow of key genes (Rieseberg 2001, Forsdyke 2004, Noor et al. 2004, Ayala \& Coluzzi 2005, Brown \& O'Neill 2010). It is fair, in this context, to remember that Michael White was the first population cytogeneticist to recognize and study the importance of changes in genetic recombination produced by re-arrangements, in the evolution of species.

\section{Epilogue}

Orthopterans accompanied the birth and development of cytogenetics through $110 \mathrm{y}$, and it seems a far cry from those incredibly detailed and laborious observations of chromosomes in sectioned material to the modern immunolocalization techniques and DNA technology of this postgenomic era. Grasshoppers have contributed enormously in all aspects of genetics and cytogenetics at all stages of this history, from the molecular and ultrastructural aspects of the chromosome, to microevolution, ecological genetics and speciation. We sincerely hope that this flow of information from our favorite research organisms will continue in the future: grasshopper chromosomes still have many things to tell us at all levels and modern technology allows us to revisit many still unsolved problems (or rediscover what the pioneer cytologists uncovered with their monocular microscopes). Michael White knew about this: 'The modern picture of karyotype evolution is thus an extremely complex one, which involves many aspects of molecular cytogenetics and biochemistry as well as the classical constraints of population genetics. Paraphrasing and altering the famous remark of Muller (1922) we may ask: "Must we evolutionists become cell physiologists, electron microscopists and molecular biologists as well as ecologists, cytogeneticists and population geneticists? Lets hope so"' (White 1975).

\section{Acknowledgments}

The authors wish to heartily thank the Orthopterists' Society, its current president María Marta Cigliano, and the Journal's editor, Glenn K. Morris, for the unique opportunity to pay tribute to one of the most outstanding cytologists and evolutionary biologists of the twentieth century. Thanks are also due to Juan Pedro Martínez Camacho for his critical reading of the manuscript and useful comments that substantially improved the original draft. Special thanks to colleagues and friends that contributed to this homage with papers of the highest quality. The authors are grateful to Dr. Carolina I Miño for critical reading of the manuscript. We greatly appreciate the help of Dr. White's son, Nicholas White. DAM acknowledges the continuous support of Consejo Nacional de Investigaciones Científicas y Técnicas (CONICET).

\section{References}

Arana P., Nicklas R.B. 1992. Orientation and segregation of a micromanipulated multivalent: familiar principles, divergent outxomes. Chromosoma 101: 399-412.

Arnold M.L., Bulger M.R., Burke J.M., Hempel A.L., Williams J.H. 1999. Natural hybridization: how low can you get and still be important? Ecology 80: 371-381.

Ault J.G. 1996. Contributions of insect systems to the chromosome theory of inheritance and to our understanding of chromosome behaviour on the spindle. International Journal of Insect Morphology and Embryology 25: 93-114.

Ayala F.J., Coluzzi M. 2005. Chromosome speciation: Humans, Drosophila, and mosquitoes. Proceedings of the National Academy of Sciences USA 102: 6535-6532.

Bakkali M., Cabrero J., López-León M.D., Perfectti F., CamachoJ.P.M. 1999.The $\mathrm{B}$ chromosome polymorphism of the grasshopper Eyprepocnemis plorans in North Africa. I. B variants and frequency. Heredity 83: 428-434.

Bakkali M., Manrique-Poyato M.I., López-León M.D., Perfectti F., Cabrero J., Camacho J.P.M. 2010. Effects of B chromosomes on egg fertility and clutch size in the grasshopper Eyprepocnemis plorans. Journal of Orthoptera Research 19: 197-203.

Basheva E.A., Torgasheva A.A., Sakaeva G.R., Bidau C., Borodin P.M. 2010. A- and B-chromosome pairing and recombination in male meiosis of the silver fox (Vulpes vulpes L., 1758, Carnivora, Canidae). Chromosome Research DOI 10.1007/s10577-010-9149-4.

Bateson W., Saunders E.R., Punnett M.A. 1904. Experimental studies in the physiology of heredity: reports to the evolution committee. Reports to the Evolution Committe of the Royal Society 2: 89---. Harrison and Sons, London.

Belař K. 1929. Beitrlge zur Kausalanalyse der Mitose. II. Untersuchungen an den Spermatocyten von Chorthippus (Stenobothrus) lineatus Panz. Wilhelm Roux' Archiv für Entwicklungsmechanic der Organismen 118: 359-480.

Benson K. 2001. T. H. Morgan's resistance to the chromosome theory. Nature Reviews Genetics 2: 469-474.

Bidau C.J. 1986. Effects on cytokinesis and sperm formation of a Bisochromosome in Metaleptea brevicornis adspersa (Acridinae, Acrididae). Caryologia 38: 165-177.

Bidau C.J. 1990. The complex Robertsonian system of Dichroplus pratensis (Melanoplinae, Acrididae). II: Effects of the fusion polymorphisms on chiasma frequency and distribution. Heredity 64: 145-159.

Bidau C.J., Hasson E.R. 1984. Population cytology of Leptysma argentina Bruner (Leptysminae, Acrididae). Genetica 62: 161-175.

Bidau C.J., Martí D.A. 1995. Male and female meiosis in Robertsonian heterozygotes of Dichroplus pratensis (Acrididae), pp 381-396. In: Brandham P.E., Bennett M.D. (Eds) Kew Chromosome Conference IV, Royal Botanic Gardens, Kew.

Bidau C.J., Martí D.A. 2002. Geographic distribution of Robertsonian fusion in Dichroplus pratensis (Melanoplinae, Acrididae): the central marginal hypothesis reanalyzed. Cytogenetic and Genome Research 96: 66-74.

Bidau C.J., Martí D.A. 2005. Variability along a latitudinal gradient in the chiasma frequency and morphological characters of Dichroplus pratensis (Orthoptera: Acrididae). European Journal of Entomology 102: 1-12.

Bidau C.J., Rosato M., Martí D.A. 2004. FISH detection of ribosomal cistrons and assortment-distortion for X and B chromosomes in Dichroplus pratensis (Acrididae). Cytogenetic and Genome Research 106: 295-301.

Boveri T. 1902. On multipolar mitoses as a means for the analysis of the cell nucleus. Verhandlungen der Physikalische-medizinischen Gesellschaft zu Würzburg 35: 67-90.

Brown J.D., O'Neill R.J. 2010. Chromosomes, conflict, and epigenetics: chromosomal speciation revisited. Annual Review of Genomics and Human Genetics 11: 291-316.

Brush S. G. 2002. How theories became knowledge: Morgan's Chromosome Theory of Heredity in America and Britain. Journal of the History of Biology 35: 471-535.

Büchner P. 1909 Das accessorische Chromosom in Spermatogenese und Ovogenese der Orthopteran, Zugleich ein Beitrag zur Kenntnis der Reduktion. Archive für. Zellforshchung 3: 335-430. 
Burt A., Bell G., Harvey P.H. 1991. Sex differences in recombination. Journal of Evolutionary Biology 4: 259-277.

Butlin R.K. 2005. Recombination and speciation. Molecular Ecology 14: 2621-2635.

Callan H.G 1949. Chromosomes. New Biologist 7: 70-88

Camacho J.P.M., Cabrero J. 1987. New hypotheses about the origin of supernumerary chromosome segments in grasshoppers. Heredity 58: 341-343.

Camacho J.P.M., R. Díaz de la Guardia, Ruiz Rejón M.. 1081. Polysomy and supernumerary isochromosomes in the grasshopper Omocestus bolivari (Chopard). Heredity 46: 123-126.

Camacho J.P.M., Navas-Castillo J., Cabrero J. 1986. Extra nucleolar activity associated with presence of a supernumerary chromosome segment in the grasshopper Oedipoda fuscocincta. Heredity 56: 237-241.

Camacho J.P.M., Sharbel T.F., Beukeboom L.W. 2000. B-chromosome evolution. Philosophical Transactions of the Royal Society of London B 55: 163-178.

Camacho J.P.M., Perfectti F., Teruel M., López-León M.D., Cabrero J. 2004. The odd-even effect in mitotically unstable B chromosomes in grasshoppers. Cytogenetic and Genome Research 106: 325-331.

Camacho J.P.M., Viseras E., Navas J., Cabrero J. 1984. C-heterochromatin content of supernumerary chromosome segments of grasshoppers: detection of an euchromatic extra segment. Heredity 53: 167-175.

Cannon W. A. 1902. A cytological basis for the Mendelian laws. Bulletin of the Torrey Botanical Club 29: 657-661.

Cano M.I., Jones G.H., Santos J.L. 1987. Sex differences in chiasmna frequency and distribution in natural populations of Eyprepocnemis plorans containing B-chromosomes. Heredity 59: 237-243.

Carlson J.G. 1936. The intergeneric homology of an atypical euchromosome in several closely related Acridinae (order Orthoptera). Journal of Morphology 59: 123-141

Carlson J.G. 1941 a. Effects of X-radiation on grasshopper chromosomes. Cold Spring Harbor Symposia on Quantitative Biology 9: 104-112.

Carlson J.G. 1941b. An analysis of x-ray induced single breaks in neuroblast chromosomes of the grasshopper (Chortophaga viridifasciata). Proceedings of the National Academy of Sciences, USA 27: 42-47.

Carlson J.G. 1952. Microdissection studies of the dividing neuroblast of the grasshopper, Chortophaga viridifasciata (De Geer). Chromosoma 5: 199-220.

Carothers E.E. 1913. The Mendelian ratio in relation to certain Orthopteran chromosomes. Journal of Morphology 24: 487-509.

Carothers E.E. 1917. The segregation and recombination of homologous chromosomes as found in two genera of Acrididae (Orthoptera). Journal of Morphology 28: 445-494.

Carothers E.E. 1921. Genetical behavior of heteromorphic homologous chromosomes of Circotettix (Orthoptera). Journal of Morphology 35: 457-483.

Carothers E.E. 1926. The maturation divisions in relation to the segregation of homologous chromosomes. Quarterly Review of Biology 1: 419-435.

Carothers E.E. 1931. The maturation divisions and segregation of heteromorphic homologous chromosomes in Acrididae (Orthoptera). Biological Bulletin 61: 324-329.

Carothers E.E. 1936. Components of the mitoticspindle with especial reference to the chromosomal and interzonal fibers in the Acrididae. Biological Bulletin 71: 460-491.

Carroll M. 1920. An extra dyad and an extra tetrad in the spermatogenesis of Camnula pellucida (Orthoptera); numerical variations in the chromosome complex within the individual. Journal of Morphology 34: 374-455.

Castillo E.R., Martí D.A., Bidau C.J. 2010. Sex- and neo-sex chromosomes in Orthoptera: a review. Journal of Orthoptera Research 19: 213-231.

Chambers R. Jr. 1914. Some physical properties of the cell nucleus. Science 40: 824-827.

Chiappero M.B., Parise C., Martí D.A., Bidau C.J., Gardenal C.N. 2004. Distribution of genetic variability in populations of two chromosomal races of Dichroplus pratensis (Melanoplinae, Acrididae) and their hybrid zone. Journal of Evolutionary Biology 17: 76-82.

Church K. 1974a. Meiosis in the grasshopper. II. Chiasma frequencies in females after elevated temperature. Heredity 32: 159-164.
Church K. 1974b. The effect of supernumerary heterochromatic chromosome segments on non-homologous chromosome associations in the grasshopper Camula pellucida. Heredity 33: 151-158.

Church K. 1979. The grasshopper X chromosome. II. Negative heteropycnosis, transcription activities and compartmentation during spermatogonial stages. Chromosoma 71: 359-370.

Cock A.G. 1989. Bateson's two Toronto addresses, 1921: 1. Chromosomal skepticism. Journal of Heredity 80: 91-95.

Coleman L.C. 1947. Chromosome abnormalities in an individual of Chorthippus longicornis (Acrididae). Genetics 32: 435-447.

Colombo G. 1952. Osservazioni cariologiche nell'oogenesi dell' Anacridium aegyptium L. (Orthoptera). Italian Journal of Zoology 19: 203-208.

Confalonieri V.A., Bidau C.J. 1986. The B-chromosomes of two species of Cylindrotettix (Leptysminae, Acrididae). Genetica 68: 87-95.

Crow E.W., Crow, J. F. 2002. 100 years ago: Walter Sutton and the chromosome theory of heredity. Genetics 160: 1-4.

Darlington C.D. 1929. Chromosome behavior and structural hybridity in the Tradescantiae. Journal of Genetics 21: 207-286

Darlington C.D. 1931. The mechanism of crossing-over. Science 73: 561562.

Darlington C.D. 1932. Recent Advances in Cytology. Blakiston, London.

Darlington C.D. 1935. Time, place and action of crossing-over. Journal of Genetics 31: 185-212.

Darlington C.D. 1936. Crossing-over and its mechanical relationships in Chorthippus and Stauroderus. Journal of Genetics 33: 465-500.

Darlington C.D. 1937. The biology of crossing-over. Nature 140: 759.

Darlington C.D. 1958. Evolution of Genetic Systems. $2^{\text {nd }}$ Edit. Oliver and Boyd, London.

Darlington C.D. 1973. The place of the chromosomes in the genetic system. Chromosomes Today 4: 1-13.

Darlington C.D., Dark S.O.S. 1932. The origin and behavior of chiasmata. II. Stenobothrus parallelus. Cytologia 3: 169-185.

Davies H.S. 1908. Spermatogenesis in Acrididae and Locustidae. Bulletin of the Museum of Comparative Zoology, Harvard 53: 49-158.

de Ia TorreJ., Lopez-Fernandez C., Nichols R., GosálvezJ. 1986. Heterochromatin readjusting chiasma distribution in two species of the genus Arcyptera: The effect among individuals and populations. Heredity 56: 177-184.

del Cerro A.L., Jones G.H., Santos J.L. 1997. Chiasma localization and incomplete synapsis in two species of Tetrigidae (Orthoptera). Chromosome Research 5: 69-71.

Egel R. 1979. Telomeres and chiasma terminalization. Hereditas 91: 138140.

Ellis G.W. 1962. Piezoelectric micromanipulators. Science 138: 84-91.

Falk R. 2005. Mendel's impact, pp. 9-29. In: Müller-Wille S., Rheinberger H.-J. (Eds). A Cultural History of Heredity III: 19th and Early 20th Centuries. Max Planck Institute for the History of Science.

Fando R.A. 2008. The unknown about a well-known biologist. Herald of the Russian Academy of Sciences 78: 160-172.

Fletcher H.L. 1977. Localised chiasmata due to partial pairing: A 3-D reconstruction of synaptonemal complexes in male Stethophyma grossum. Chromosoma 65: 247-269.

Forsdyke D.R. 2004. Chromosomal speciation: a reply. Journal of Theoretical Biology 230: 189-196.

Fox D.P. 1973. The control of chiasma distribution in the locust, Schistocerca gregaria (Forskål). Chromosoma 43: 289-328.

Goldschmidt R. 1917 Crossing over ohne Chiasmatypie? Genetics 2: 82-95.

Granado N., Rebollo E., Sánchez FJ., Arana P. 2004. B chromosomes: the troubles of integration. Cytogenetic and Genome Research 106: 402410

Green D.M.1990. Muller's Ratchet and the evolution of supernumerary chromosomes. Genome 33: 818-824.

Grieco M.L., Bidau C.J. 1999. Chiasma frequency and distribution in males and females of Metaleptea brevicornis adspersa (Acridinae, Acrididae) with and without B chromosomes. Hereditas 131: 101-107.

Grieco M.L., Bidau C.J. 2000. The dicentric nature of the metacentric B chromosome of Metaleptea brevicornis adspersa (Acridinae, Acrididae). Heredity 84: 639-646. 
Guzman N.V., Confalonieri V.A.. 2010. The evolution of South American populations of Trimerotropis pallidipennis (Oedipodinae: Acrididae) revisited: dispersion routes and origin of chromosomal inversion clines. Journal of Orthoptera Research 19: 253-260.

Harman M.T. 1915. Spermatogenesis in Paratettix. Biological Bulletin 29: 262-277.

Harman M.T. 1920. Chromosome studies in Tettigidae. II. Chromosomes of Parattetix BB and CC and their hybrid BC.

Hegreness M., Meselson M. 2007. What didSutton see?:Thirtyyears of confusion over the chromosomal basis of Mendelism. Genetics 176: 1939-1944.

Henderson S.A. 1962. Temperature and chiasma formation in Schistocerca gregaria. II. Cytological effects at $40^{\circ} \mathrm{C}$ and the mechanism of heat-induced univalence. Chromosoma 13: 437-463.

Henderson S.A. 1988. Four effects of elevated temperature on chiasma formation in the locust Schistocerca gregaria. Heredity 60: 387-601.

Henderson S.A., Koch C.A. 1970. Co-orientation stability ny physical tension: a demonstration with experimentally interlocked bivalents. Chromosoma 29: 207-216.

Henriques-Gil N., Jones G.H., Cano M.I., Arana P., Santos J.L. 1986. Female meiosis during oocyte maturation in Eyprepocnemis plorans (Orthoptera, Acrididae). Canadian Journal of Genetics and Cytology 28: 84-87.

Hewitt G.M. 1973a. The integration of supernumerary chromosomes into the orthopteran genome. Cold Spring Harbor Symposia on Quantitative Biology 3*: 183-194.

Hewitt G.M.1973b. Variable transmission rates of a B chromosome in Myrmeleotettix maculatus (Thunb.). Chromosoma 40: 83-106.

Hewitt G.M. 1973c. Evolution and maintenance of B chromosomes. Chromosomes Today 4: 351-369.

Hewitt G.M. 1979 Grasshopper and crickets, pp. 1-170. In: John B. (Ed.) Animal Cytogenetics. 3. Insecta 1 Orthoptera, Gebruder Borntraeger, Berlin and Stuttgart.

Inoue S. 1953. Polarization optical studies of the mitotic spindle. I. The demonstration of spindle fibers in living cells. Chromosoma 5: 487500.

Janssens F.A. 1909. La théorie de la chiasmatypie. La Cellule 22: 389-411.

Janssens F.A. 1924. La chiasmatypie dans les insectes. La Cellule 34:135359.

John B. 1973. The cytogenetic systems of grasshoppers and locusts. II. The origin and evolution of supernumerary segments. Chromosoma 44: 123-146.

John B. 1990. Meiosis. Cambridge University Press, Cambridge.

John, B., Appels R., Contreras N. 1986. Population cytogenetics of Atractomorpha similis. I. Molecular cytogenetics of the distal C-band polymorphism. Chromosoma 94: 45-68.

John B., Hewitt G.M. 1966. A polymorphism for heterochromatic supernumerary segments in Chorhippus parallelus. Chromosoma 18: 254-271.

John B., King M. 1977. Heterochromatin variation in Cryptobothrus chrysophorus. II. Patterns of C-banding. Chromosoma 65: 59-79.

John B., King M. 1982. Meiotic effects of supernumerary heterochromatin in Heteropternis obscurella. Chromosoma 85: 39-65.

John B., King M. 1985. Pseudoterminalisation, terminalisation, and nonchiasmate modes of terminal association. Chromosoma 93: 89-99.

John B., King M. 1985. Pseudoterminalistion, terminalisation, and nonchiasmate modes of terminal association. Chromosoma 92: 89-99.

Jones G.H. 1973. Light and electron microscope studies of chromosome pairing in relation to chiasma localisation in Stethophyma grossum (Orthoptera: Acrididae). Chromosoma 42: 145-162.

Jones G.H.1978. Giemsa C-banding of rye meiotic chromosomes and the nature of "terminal" chiasmata. Chromosoma 66: 45-57.

Jones G.H., Stamford W.E., Perry P.E. 1975. Male and female meiosis in grasshoppers. II. Chorthippus brunneus. Chromosoma 51: 381-389.

Jones G.H., Tease C. 1984. Analysis of exchanges in differentially stained meiotic chromosomes of Locusta migratoria after BrdU substitution and FPG staining. IV. The nature of 'terminal associations'. Chromosoma 89: 33-36.

Jones G.H., Wallace B.M.N. 1980. Meiotic chromosome pairing in Stethophyma grossum spermatocytes studied by a surface-spreading and silver-staining technique. Chromosoma 78: 189-201.
Jones R.N. 1991. B-chromosome drive. American Naturalist 137: 430-442.

Jones R.N. 1995. Tansley Review No. 85: B chromosomes in plants. New Phytologist 131: 411-434.

Kanda N., Kato H. 1980. Analysis of crossing over in mouse meiotic cells by BrdU labeling technique. Chromosoma 78: 113-121.

Kite G.L., Chambers R. Jr. 1912. Vital staining of chromosomes and the function and structure of the nucleus. Science 36: 639-641.

Lenormand T., Dutheil J. 2005. Recombination difference between sexes: a role for haploid selection. PloS Biology 3: e63.

Lewis D. 1982. Cyril Dean Darlington 1903-1981. Heredity 48: 161-167.

López-Fernández C., Pradillo E., Zabal-Aguirre M., Fernández J.L., García de la Vega C., Gosálvez J. 2004. Telomeric and interstitial telomeric-like DNA sequences in Orthoptera genomes. Genome 47: 757-763.

López-León M.D., Cabrero J., Camacho J.P.M., Cano M.I., Santos J.L. 1992. A widespread B chromosome polymorphism maintained without apparent drive. Evolution 46: 529-539.

López-León MD, M.C. Pardo, J. Cabrero, E. Viseras, J.P.M. Camacho, Santos J.L. . 1993. Generating high variability of B chromosomes in the grasshopper Eyprepocnemis plorans. Heredity 71: 352-362.

Manrique-Poyato M.I., Muñoz-Pajares A.J., Loreto V., López-León M.D., Cabrero J., Camacho J.P.M. 2006. Causes of B chromosome variant substitution in the grasshopper Eyprepocnemis plorans . Chromosome Research 14: 693-700.

Marchant A.D., Arnold M.L., WIkinson P. 1988. Gene flow across a chromosomal tension zone. I. Relicts of ancient hybridization. Heredity 51: 321-328.

Martí D.A., Bidau C.J. 1995. Male and female meiosis in a natural population of Dichroplus pratensis (Acrididae) polymorphic for Robertsonian translocations: A study of chiasma frequency and distribution. Hereditas 123: 227-235.

Martins L. A. -C.P. 1998. Thomas Hunt Morgan e a Teoria Cromossómica: de crítico a defensor. Episteme 6: 100-126.

Martins L. A. -C.P. 1999. Did Sutton and Boveri propose the so-called SuttonBoveri chromosome hypothesis? Genetics and Molecular Biology 22: 261-271.

McClung C.E. 1899. A peculiar nuclear element in the male reproductive cells of insects. Zoological Bulletin 1-2: 187-197.

McClung C.E. 1900. The spermatocyte divisions of the Acrididae. Kansas University Quarterly 9: 73-100.

McClung C.E. 1901. Notes on the accessory chromosome. Anatomischer Anzeiger 20: 220-226.

McClung C.E. 1902. The accessory chromosome-Sex determinant? Biological Bulletin 3: 43-84.

McClung C.E.1905. The chromosome complex of Orthoperan spermatocytes. Biological Bulletin 9: 304-340.

McClung C.E. 1914. A comparative study of the chromosomes in Orthopteran spermatogenesis. Journal of Morphology 25: 651-749.

McClung C.E. 1916. The multiple chromosomes of Hesperotettix and Mermiria (Orthoptera). Journal of Morphology 29: 181-264.

McClung C.E. 1917. The multiple chromosomes of Hesperotettix and Mermiria. Journal of Morphology 29: 181-264.

McClung C.E. 1927. Synapsis and related phenomena in Mecostethus and Leptysma (Orthoptera). Journal of Morphology 43: 181-265.

McClung C.E. 1927. The chiasmatype theory of Janssens. Quarterly Review of Biology 2: 344-366.

Meek C.F.U. 1911. The spermatogenesis of Stenobothrus viridulus; with special reference to the heterotropic chromosome as a sex determinant in grasshoppers. Journal of the Linnean Society of London, Zoology 32: $1-21$.

Miño C.I., Gardenal C.N., Bidau C.J. 2010. Morphological, genetic and chromosomal variation at a small spatial scale within a mosaic hybrid zone of Dichroplus pratensis Bruner (Acrididae). Journal of Heredity, in press.

Morgan T. H., Sturtevant A. H., Muller H. J., Bridges C. B. 1915. The Mechanism of Mendelian Heredity. Henry Holt and Co.,New York.

Morgan T.H. 1910. Chromosomes and heredity. American Naturalist 44: 449-496. 
Morgan T.H., Cattell E. 1912. Data for the study of sex linked inheritance in Drosophila. Journal of Experimental Zoology 13: 79-101.

Muller H.J. 1916. The mechanism of crossing-over. II. IV. The manner of occurrence of crossing-over. American Naturalist 50: 284-305.

Nabours R.K. 1914. Studies of inheritance and evolution in Orthoptera. I. Paratettix texanus. Journal of Genetics 3: 141-170.

Nabours R.K. 1917. Studies of inheritance in Orthoptera II and III. Paratettix texanus and a mutant. Journal of Genetics 7: 1-54.

Nabours R.K. 1919 Parthenogenesis and crossing-over in the grouse locust Apotetlix. American Naturalist 53:131-142.

Nabours R.K., Robertson W.R.B. 1933. An X-ray induced chromosomal translocation in Apotettix eurycephalus Hancock (grouse locusts). Proceedings of the National Academy of Sciences, USA 19: 234-239.

Navas-Castillo J., Cabrero J., Camacho J.P.M. 1985. Chiasma redistribution in bivalents carrying supernumerary chromosome segments in grasshoppers. Heredity 55: 245-248.

Navas-Castillo J., Cabrero J., Camacho J.P.M. 1987. Chiasma redistribution in presence of supernumerary chromosome segments in grasshoppers: dependence on the size of the extra segment. Heredity 58: 409-412.

Nicklas R.B., Staehly C.A. 1967. Chromosome micromanipulation. I. The mechanics of chromosome attachment to the spindle. Chromosoma 21: $1-16$.

Nicklas R. B. 1961. Recurrent pole-to-pole movements of the sex chromosome during prometaphase I in Melanoplus differentialis spermatocytes. Chromosoma 12: 97-115.

Noor M.A.F., Grams K.L., Bertucci L.A., Reiland J. 2001. Chromosomal inversions and the reproductive isolation of species. Proceedings of the National Academy of Sciences USA 98: 12084-12088.

Nur U. 1961. Meiotic behaviour of an unequal bivalent in the grasshopper Calliptamus palaestinensis Bdhr. Chromosoma 12: 272-279.

Nur U. 1981. Undercondensation and localized euchromatinization of the X chromosome in the grasshopper Melanoplus femur-rubrum. Chromosoma 82: 353-365.

Pardo M.C., Lopez-Leon M.D., Cabrero J., Camacho J.P.M.. 1995. Cytological and developmental analysis of tychoparthenogenesis in Locusta migratoria. Heredity 75: 485-494.

PayneF. 1909. Some new types of chromosome distribution and their relation to sex. Biological Bulletin 16: 153-166.

PayneF. 1912. The chromosomes of Gryllotalpa borealis. Archivs fürZellforschung 9: $141-148$.

Peacock W.J., McCann D. 2010. Michael James Denham White 1910-1983. Journal of Orthoptera Research 19: 183-194.

Perry P.E., Jones G.H. 1974. Male and female meiosis in grasshoppers. I. Stethophyma grossum. Chromosoma 47: 227-236.

Pinney M.E. 1908. Organization of the chromosomes in Phrynotettix magnus. Kansas University Science Bulletin 4: 307-316.

Plough H. 1917. The effect of temperature on crossing-over in Drosophila. Journal of Experimental Zoology 24: 148-209.

Plough H. 1921. Further studies on the effect of temperature on crossing-over. Journal of Experimental Zoology 32: 187-202.

Plough H. 1924. Radium radiations and crossing over. American Naturalist 58: 85-87.

Randolph L.F. 1928. Types of supernumerary chromosomes in maize. Anatomical Record 41: 102.

Rebollo E., Arana P. 1998. Chromosomal factors affecting the transmission of univalents. Chromosome Research 6: 67-69.

Rebollo E., Arana P. 2000. Active role of lagging chromosomes in spindle collapse as revealed by live phase contrast and tubulin immunostaining. Chromosoma 110: 292-304

Richmond M.L., Dietrich M.R. 2002. Richard Goldschmidt and the crossingover controversy. Genetics 161: 477-482.

Rieger R., Michaelis A., Green M. 1976. Glossary of Genetics and Cytogenetics. Springer Verlag, Berlin, Heodelberg, New York.

Rieseberg L.H. 2001. Chromosomal rearrangements and speciation. Trends in Ecology and Evolution 16: 351-358.

Ris H. 1949. The anaphase movement of chromosomes in the spermatocytes of the ghrasshopper. Biological Bulletin 96: 90-106.
Robertson W.R.B. 1908. The chromosome complex of Syrbula admirabilis. Kansas University Science Bulletin 4: 273-305.

Robertson W.R.B. 1916a. Chromosomestudies. III. Inequalities and deficiencies in homologous chromosomes: their bearing upon synapsis and the loss of unit characters. Journal of Morphology 26: 109-141.

Robertson W.R.B. 1916b. Chromosome studies. I. Taxonomic relationships shown in the chromosomes of Tettigidae and Acrididae V-shaped chromosomes and their significance in Acrididae, Locustidae and Gryllydae: chromosomes and variation. Journal of Morphology 27: 197-331.

Robertson W.R.B. 1931. Chromosome studies. II. Synapsis in the Tettigidae with special reference to the pre-synapsis split. Journal of Morphology 51: 119-146.

Rodríguez-Iñigo E., Mason P.L., Rufas J.S., García de la Vega C. 1998. Effects of supernumerary heterochromatin on chiasma formation and chromosome segregation in Dociostaturus genei (Orthoptera). Heredity 80: 353-360.

Sáez F.A. 1930. Organización y número de cromosomas en los ortópteros de América del Sur. Proceedings International Congress of Biology, Montevideo: 1-8.

Santos J.L. 1993. The effect of supernumerary segments on recombination in Euchorthippus pulvinatus (grasshopper): a comparative study between sexes and populations. Heredity 70: 130-134.

Santos J.L., Ciprés H., Lacadena J.R. 1989. A quantitative study of chiasma terminalization in the grasshopper Chorthippus jucundus. Heredity 62: 51-57.

Santos J.L., del Cerro A.L., Fernández A., Díez M. 1993. Meiotic behaviour of $\mathrm{B}$ chromosomes in the grasshopper Omocestus burri: A case of drive in females. Hereditas 118: 139-143.

Satzinger H. 2005. The chromosomal theory of heredity and the problem of gender equality in the work of Theodor and Marcella Boveri, pp. 101114. In: Müller-Wille S., Rheinberger H.-J. (Eds). A Cultural History of Heredity III: 19th and Early 20th Centuries. Max Planck Institute for the History of Science.

Schmidt W.J. 1939. Doppelbrechung der Kernspindel und Zugfasertheorie der Chromosomenbewegung. Chromosoma 1: 253-264.

Schwartz J. 2008. In Pursuit of the Gene, from Darwin to DNA. Harvard University Press, Cambridge and London.

Shaw D.D. 1976. Population cytogenetics of the genus Caledia (Orthoptera: Acridinae). I. Inter- and intraspecific karyotype diversity. Chromosoma 54: 221-243.

Shaw D.D., Marchant A.D., Arnold M.L., Contreras N. 1987. Chromosomal rearrangements, ribosomal genes and mitochondrial DNA: contrasting patterns of introgression across a narrow hybrid zone. pp. In Brandham P.E., Bennett M.D. (Eds), Kew Chromosome Conference.III. Allen and Unwin, London.

Shaw D.D., Moran C., Wilkinson, P. 1980. Chromosomal reorganisation, geographic differentiation and the mechanism of speciation in the genus Caledia. pp. 171-194. In Blackman R.L., Hewitt G.M., Ashburner, M. (Eds). Royal Entomological Society Symposium X. Insect Cytogenetics. Blackwell, Oxford,

Stern C. 1950. Boveri and the early days of genetics. Nature 166: 446.

Stevens N.M. 1905. Studies in spermatogenesis with special reference to the "accessory chromosome". Carnegie Institution of Washington, Pub. 36: $1-32$.

Stevens N.M. 1908a. A study of the germ cells of certain Diptera, with reference to the heterochromosomes and the phenomena of synapsis. Journal of Experimental Zoology 5: 359-383.

Stevens N.M. 1908b. The chromosomes in Diabrotica vittata, Diabrotica soror and Diabrotica 12-punctata. A contribution to the literature on heterochromosomes and sex determination. Journal of Experimental Zoology 5: 453-470.

Stevens N.M. 1912a. Supernumerary chromosomes, and synapsis in Ceuthophilus (sp.?). Biological Bulletin 22: 219-230.

Stevens N.M. 1912b. Further observations on supernumerary chromosomes and sex ratios in Diabrotica soror. Biological Bulletin 22: 231-238.

Sturtevant A. H. 1965 A History of Genetics. Harper \& Row, New York..

Sturtevant A.H. 1917 Crossing over without chiasmatype? Genetics 2: 301304. 
Suja J.A., Antonio C., Garcia de la Vega C., Rufas J.S. 1994. Supernumerary chromosome segments and intrabivalent chiasma redistribution in Pyrgomorpha conica (Orthoptera). Heredity 73: 1-10.

Sutton W.S. 1900. The spermatogonial divisions of Brachystola magna. Kansas University Quarterly 9: 135-160.

Sutton W.S. 1902. On the morphology of the chromosomegroup in Brachystola magna. Biological Bulletin 4: 24-39.

Sutton W. S. 1903. The chromosomes in heredity. Biological Bulletin 4: 231-251.

Sybenga J. 1975. Meiotic configurations. Springer Verlag, Berlin, Heidelberg, New York.

Tease C., Jones G.H. 1978. Analysis of exchanges in differentially stained meiotic chromosomes of Locusta migratoria after BrdU substitution and FPG staining. I. Crossover exchanges in monochiasmate bivalents. Chromosoma 69: 163-178.

Teruel M., Cabrero J., Perfectti F., Alché J.D., Camacho J.P.M. 2009. Abnormal spermatid formation in the presence of the parasitic B 24 chromosome in the grasshopper Eyprepocnemis plorans. Sexual Development 3: 284-289.

Trivers R. 1988. Sex differences in rates of recombination and sexual selection, pp. 270-286. In: Michod R.E., Levin B.R. (Eds), The Evolution of Sex: An Examination of Current Ideas. Sinauer Associates, Sunderland.

Viera A., Santos J.L., Rufas J.S. 2009. Relationship between incompletesynapsis and chiasma localization. Chromosoma 118: 377-389.

Viera A., Santos J.L., Parra M.T., Calvente A., Gómez R., de la Fuente R., Suja J.A. Page J., de la Vega C.G., Rufas J.S. 2010. Incomplete synapsis and chiasma localization: the chicken or the egg? Cytogenetic and Genome Research DOI: 10.1159/000290637

Viera A., Calvente A., Pradillo M., Rufas J.S., Santos J.L. 2010b. Meiosis in Stethophyma (Mecostethus) grossum (Orthoptera: Acrididae): an exciting history. Journal of Orthoptera Research 19: 267-273.

Wenrich D.H. 1916. The spermatogenesis of Phrynotettix magnus, with special reference to synapsis and the individuality of chromosomes. Bulletin of the Museum of Comparative Zoology, Harvard 60: 57-135.

White M.J.D. 1934. The influence of temperature on chiasma frequency. Journal of Genetics 29: 203-215.

WhiteM.J.D. 1935. EineneueFormvon Tetraploidienach Roentgenbestrahlung. Naturwissenschaften 23: 390-391.

White M.J.D. 1936. Chiasma localization in Mecostethus grossus L, and Metrioptera brachyptera L. Zeitschrift für Zellforschung 24: 128-135.

White M.J.D. 1937a. The effects of X-rays on mitosis in the spermatogonial divisions of Locusta migratoria L. Proceedings of the Royal Society of London B 119: 61-84.

White M.J.D. 1937b. The effect of X-rays on the first meiotic division in three species of Orthoptera. Proceedings of the Royal Society of London B 124: 183-196.

White M.J.D. 1938. A new and anomalous type of meiosis in a Mantid, Callimantis antillarum Saussure. Proceedings of the Royal Society of London B 125: 516-523.

White M.J.D. 1940a. The heteropycnosis of sex-chromosomes and its interpretation in terms of spiral structure. Journal of Genetics 40: 6782.

White M.J.D. 1940b. The origin and evolution of multiple sex chromosome mechanisms. Journal of Genetics 40: 303-336.

White M.J.D. 1940c. A translocation in a wild population of grasshoppers. Journal of Heredity 31: 137-140.

White M.J.D. 1941a. Theevolution of the sexchromosomes. I.TheXO and XIX2Y mechanisms in praying mantids. Journal of Genetics 42: 143-172.

White M.J.D. 1941b. The evolution of the sex chromosomes. II. The Xchromosome in the Tettigoniidae and the Acrididae and the principle of "evolutionary isolation" of the X. Journal of Genetics 42: 173-190.

White M.J.D. 1943. Amount of heterochromatin as a specific character. Nature 152: 536-537.

White M. J. D. 1945. Animal Cytology and Evolution. viii + 375 pp. Cambridge: Cambridge University Press.

White M.J.D. 1949. A cytological survey of wild populations of Trimerotropis and Circotettix (Orthopera, Acrididae). I. The chromosomes of twelve species. Genetics 34:537-563.
White M.J.D. 1951a. Cytogenetics of orthopteroid insects. Advances in Genetics 4: 267-330.

White M.J.D. 1951b. A cytological survey of wild populations of Trimerotropis and Circotettix (Orthopera, Acrididae). II. Racial differentiation in T. sparsa. Genetics 36: 31-53.

White M.J.D. 1951c. Structural heterozygosity in natural populations of the grasshopper Trimerotropis sparsa. Evolution 5: 376-394.

White M.J.D. 1954. An extreme form of chiasma localization in a species of Bryodema (Orthoptera, Acrididae). Evolution 8: 350-358.

White M.J.D. 1957. Cytogenetics of the grasshopper Moraba scurra. I. Meiosis of interracial and interpopulation hybrids. Australian Journal of Zoology 5: 285-304.

WhiteM.J.D. 1958. Restrictions on recombination in grasshopper populations and species. Cold Spring Harbor Symposium on Quantitative Biology 23: 307-317.

White M.J.D. 1960. Between inversion polymorphisms on two different chromosome pairs in the grasshopper Moraba scurra. Evolution 14: 116-129.

White M.J.D. 1963. Cytogenetics of the grasshopper Moraba scurra. VIII. A complex spontaneous translocation. Chromosoma 14: 140-145.

White M.J.D. 1964. Cytogenetic mechanisms in insect reproduction. pp.1-12. In: Highnam K.C. (Ed.). Insect Reproduction, Symposium N², Royal Entomological Society, London.

White M.J.D. 1965a. Chiasmata and achiasmatic meiosis in African Eumastacid grasshoppers. Chromosoma 16: 271-307.

White M.J.D. 1965b. Sex chromosomes and meiotic mechanisms in some African and Australian Mantids. Chromosoma 16: 521-547.

White M.J.D. 1968. Models of speciation. Science 159: 1065-1070.

White M.J.D. 1969. Chromosomal rearrangements and speciation in animals. Annual Review of Genetics 3: 75-98.

White M.J.D. 1970. Asymmetry of heteropycnosis in tetraploid cells of a grasshopper. Chromosoma 30: 51061.

White M.J.D. 1975a. An XY sex chromosome mechanism in a mantid with achiasmatic meiosis. Chromosoma. 51: 93-97.

White M.J.D. 1975b. Chromosomal repatterning-regularities and restrictions. Genetics 79: 63-72.

White M.J.D. 1977. Animal Cytology and Evolution. $3^{\text {rd }}$ Edit. Cambridge University Press, Cambridge.

White M.J.D. 1978. Modes of Speciation. W.H. Freeman, San Francisco.

White M.J.D., Cheney J., Key K.H.L. 1963.a A parhenogenetic species of grasshopper with complex structural heterozygosity (Orthoptera: Acridoidea). Australian Journal of Zoology 11: 1-19.

White M.J.D., Lewontin R.C., Andrew L.E. 1963b. Cytogenetics of the grasshopper Moraba scurra. VII. Geographic variation of adaptive properties of inversions. Evolution 17: 147-162.

White M.J.D., Morley F.H.W. 1955. Effects of pericentric rearrangements on recombination in grasshopper chromosomes. Genetics 40: 604-619.

White M.J.D., Nickerson N.H. 1951. Structural heterozygosity in a very rare species of grasshopper. American Naturalist 85: 239-246.

Wise D., Rickards G.K. 1977. A quadrivalent studied in living and fixed grasshopper spermatocytes. Chromosoma 63: 305-315.

Wolf K.W. 1994. How meiotic cells deal with non-exchange chromosomes. Bioessays 16: 107-114.

Woolsey C.I. 1915. Linkage of chromosomes correlated with reduction in numbers among the species of a genus, also within a species of the Locustidae. Biological Bulletin 28: 163-186. 